CRYSTALLOGRAPHIC COMMUNICATIONS

ISSN 2056-9890

Received 4 June 2019

Accepted 9 July 2019

Edited by A. J. Lough, University of Toronto, Canada

Keywords: crystal structure; pyridazine; dioxolo; Hirshfeld surface; electrochemical measurements.

CCDC reference: 1939591

Supporting information: this article has supporting information at journals.iucr.org/e

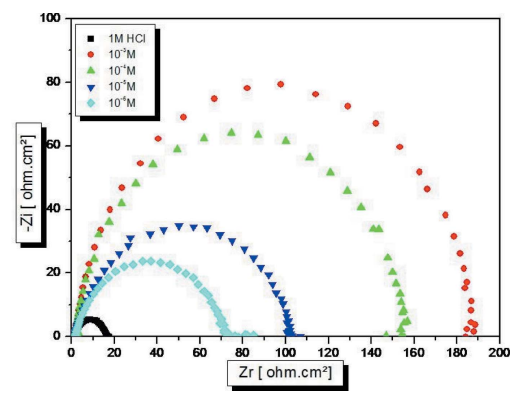

OPEN $\odot$ ACCESS

\section{Crystal structure, Hirshfeld surface analysis and corrosion inhibition study of 3,6-bis(pyridin-2-yl)-4- $\{[(3 \mathrm{a} S, 5 S, 5 \mathrm{a} R, 8 \mathrm{a} R, 8 \mathrm{bS})-2,2,7,7$-tetramethyltetra- hydro-5H-bis[1,3]dioxolo[4,5-b:4',5'-d]pyran-5-yl)- methoxy]methyl\}pyridazine monohydrate}

\author{
Mouad Filali, ${ }^{a *}$ Hicham Elmsellem, ${ }^{b}$ Tuncer Hökelek, ${ }^{c}$ Abdelkrim El-Ghayoury, d \\ Oleh Stetsiuk, ${ }^{\text {d }}$ El Mestafa El Hadrami ${ }^{a}$ and Abdessalam Ben-Tama ${ }^{a}$
}

\begin{abstract}
aLaboratoire de Chimie Organique Appliquée, Université Sidi Mohamed Ben Abdallah, Faculté des Sciences et Techniques, Route d'Immouzzer, BP 2202, Fez, Morocco, 'baboratoire de Chimie Analytique Appliquée, Matériaux et Environnement (LC2AME), Faculté des Sciences, BP 717, 60000 Oujda, Morocco, ' Department of Physics, Hacettepe University, 06800 Beytepe, Ankara, Turkey, and 'Laboratoire MOLTECH-Anjou, UMR 6200, CNRS, UNIV Angers 2 bd Lavoisier, 49045 Angers Cedex, France. *Correspondence e-mail: mmouadfilali10@gmail.com
\end{abstract}

In the title compound, $\mathrm{C}_{27} \mathrm{H}_{30} \mathrm{~N}_{4} \mathrm{O}_{6} \cdot \mathrm{H}_{2} \mathrm{O}$, the two dioxolo rings are in envelope conformations, while the pyran ring is in a twisted-boat conformation. The pyradizine ring is oriented at dihedral angles of $9.23(6)$ and $12.98(9)^{\circ}$ with respect to the pyridine rings, while the dihedral angle between the two pyridine rings is $13.45(10)^{\circ}$. In the crystal, $\mathrm{O}-\mathrm{H}_{\text {water }} \cdots \mathrm{O}_{\text {pyran }}, \mathrm{O}-\mathrm{H}_{\text {water }} \cdots \mathrm{O}_{\text {methoxymethyl }}$ and $\mathrm{O}-\mathrm{H}_{\text {water }} \cdots \mathrm{N}_{\text {pyridazine }}$ hydrogen bonds link the molecules into chains along [010]. In addition, weak $\mathrm{C}-\mathrm{H}_{\text {dioxolo }} \cdots \mathrm{O}_{\text {dioxolo }}$ hydrogen bonds and a weak $C-$ $\mathrm{H}_{\text {methoxymethyl }} \cdots \pi$ interaction complete the three-dimensional structure. The Hirshfeld surface analysis of the crystal structure indicates that the most important contributions for the crystal packing are from $\mathrm{H} \cdots \mathrm{H}(55.7 \%), \mathrm{H} \cdots \mathrm{C} /$ $\mathrm{C} \cdots \mathrm{H}(14.6 \%), \mathrm{H} \cdots \mathrm{O} / \mathrm{O} \cdots \mathrm{H}(14.5 \%)$ and $\mathrm{H} \cdots \mathrm{N} / \mathrm{N} \cdots \mathrm{H}(9.6 \%)$ interactions. Hydrogen-bonding and van der Waals interactions are the dominant interactions in the crystal packing. Electrochemical measurements are also reported.

\section{Chemical context}

Given their importance in the pharmaceutical, chemical and industrial fields, the synthesis of 3,6-di(pyridin-2-yl)pyridazine and its derivatives has been a goal of chemists in recent years. 5-[3,6-Di(pyridin-2-yl)pyridazine-4-yl]-2'-deoxyuridine- $5^{\prime}-O$ triphosphate can be used as a potential substrate for fluorescence detection and imaging of DNA (Kore et al., 2015). Systems containing this moiety have also shown remarkable corrosion inhibitory (Khadiri et al., 2016). Heterocyclic molecules such as 3,6-bis (2'-pyridyl)-1,2,4,5-tetrazine have been used in transition-metal chemistry (Kaim \& Kohlmann, 1987). This bidentate chelate ligand is popular in coordination chemistry and complexes of a wide range of metals, including iridium and palladium (Tsukada et al., 2001). We report herein the synthesis and the molecular and crystal structures of the title compound, (I), along with the Hirshfeld surface analysis and its corrosion inhibition properties.

\section{Structural commentary}

The title molecule contains two dioxolo, two pyridine, one pyridazine and one pyran rings (Fig. 1). The pyridazine ring is linked to the pyran ring through the methoxymethyl moiety. 
The two dioxolo rings, $B(\mathrm{O} 2 / \mathrm{O} 3 / \mathrm{C} 2-\mathrm{C} 4)$ and $C(\mathrm{O} 4 / \mathrm{O} 5 / \mathrm{C} 5-$ $\mathrm{C} 7)$, are in envelope conformations. Atoms $\mathrm{O} 3$ and $\mathrm{O} 4$ are at the flap positions and are displaced by $0.442(2)$ and -0.397 (2) $\AA$, respectively, from the least-squares planes of the four atoms. A puckering analysis of the pyran ring $A(\mathrm{O} 1 /$ $\mathrm{C} 1 / \mathrm{C} 2 / \mathrm{C} 4-\mathrm{C} 6)$, gave the parameters $Q_{\mathrm{T}}=0.6508(25) \AA, q_{2}=$ $0.6451(25) \AA, q_{3}=-0.0865(26) \AA, \varphi=214.6(2)^{\circ}$ and $\theta=$ $97.64(23)^{\circ}$, indicating a twisted-boat conformation. The pyradizine ring $D(\mathrm{~N} 1 / \mathrm{N} 2 / \mathrm{C} 14-\mathrm{C} 17)$ is oriented at dihedral angles of $9.23(6)$ and $12.98(9)^{\circ}$, respectively, to the pyridine rings $E(\mathrm{~N} 3 / \mathrm{C} 18-\mathrm{C} 22)$ and $F(\mathrm{~N} 4 / \mathrm{C} 23-\mathrm{C} 27)$, while the dihedral angle between the two pyridine rings is $13.45(10)^{\circ}$. The methoxymethyl moiety is nearly co-planar with the pyradizine ring, as indicated by the $\mathrm{O} 6-\mathrm{C} 13-\mathrm{C} 14-\mathrm{C} 15$ torsion angle of $-172.8(2)^{\circ}$.

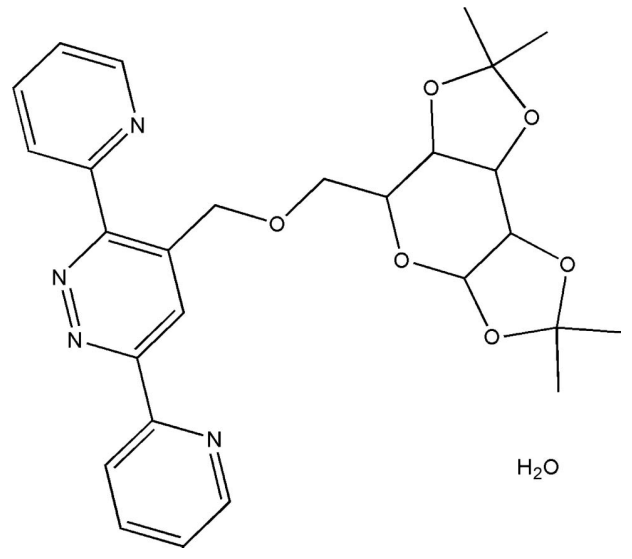

\section{Supramolecular features}

In the crystal, $\mathrm{O}-\mathrm{H}_{\text {water }} \cdots \mathrm{O}_{\text {pyran }}, \mathrm{O}-\mathrm{H}_{\text {water }} \cdots \mathrm{O}_{\text {methoxymethyl }}$ and $\mathrm{O}-\mathrm{H}_{\text {water }} \cdots \mathrm{N}_{\text {pyridazine }}$ hydrogen bonds (Table 1 and Fig. 2) link the molecules, forming chains along [010]. The

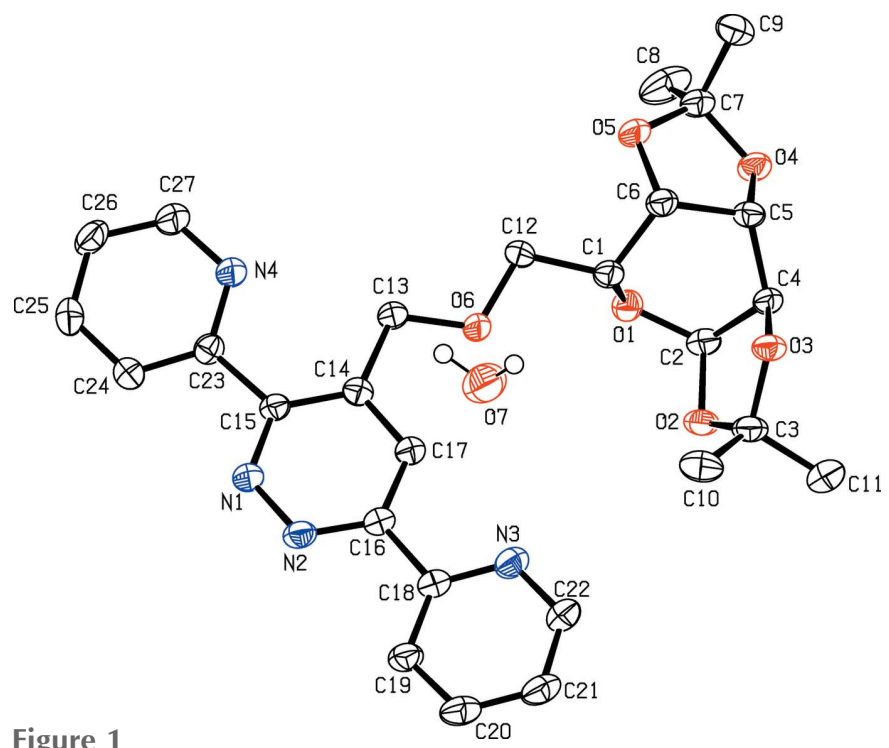

The molecular structure of the title compound with the atom-numbering scheme. Displacement ellipsoids are drawn at the $50 \%$ probability level. $\mathrm{H}$ atoms bonded to $\mathrm{C}$ atoms are not shown.
Table 1

Hydrogen-bond geometry $\left(\AA,^{\circ}\right)$.

$C g$ is the centroid of the N3/C18-C22 ring.

\begin{tabular}{lllll}
\hline$D-\mathrm{H} \cdots A$ & $D-\mathrm{H}$ & $\mathrm{H} \cdots A$ & $D \cdots A$ & $D-\mathrm{H} \cdots A$ \\
\hline $\mathrm{O} 7-\mathrm{H} 7 A \cdots \mathrm{N} 2^{\mathrm{i}}$ & $0.84(2)$ & $2.18(3)$ & $3.019(4)$ & $172(6)$ \\
$\mathrm{O} 7-\mathrm{H} 7 B \cdots \mathrm{O} 1$ & $0.86(2)$ & $2.30(3)$ & $3.112(4)$ & $157(6)$ \\
$\mathrm{O} 7-\mathrm{H} 7 B \cdots \mathrm{O} 6$ & $0.86(2)$ & $2.57(5)$ & $3.176(5)$ & $129(5)$ \\
$\mathrm{C} 2-\mathrm{H} 2 \cdots 3^{\mathrm{ii}}$ & 0.98 & 2.51 & $3.444(4)$ & 160 \\
$\mathrm{C} 12-\mathrm{H} 12 A \cdots C g^{\text {iv }}$ & 0.97 & 3.07 & $3.761(3)$ & 130 \\
\hline
\end{tabular}

Symmetry codes: (i) $\quad-x, y-\frac{1}{2},-z+\frac{1}{2} ; \quad$ (ii) $\quad x-\frac{1}{2},-y+\frac{1}{2},-z+1$; (iv)

$-x+1, y-\frac{1}{2},-z+\frac{1}{2}$

hydrogen bond involving $\mathrm{H} 7 B$ is bifurcated. In addition, weak $\mathrm{C}-\mathrm{H}_{\text {dioxolo }} \cdots \mathrm{O}_{\text {dioxolo }}$ hydrogen bonds and a weak $\mathrm{C}-$ $\mathrm{H}_{\text {methoxymethyl }} \cdots \pi$ interaction complete the three-dimensional structure.

\section{Hirshfeld surface analysis}

In order to visualize the intermolecular interactions in the crystal of the title compound, a Hirshfeld surface (HS) analysis (Hirshfeld, 1977; Spackman \& Jayatilaka, 2009) was carried out by using CrystalExplorer17.5 (Turner et al., 2017). In the HS plotted over $d_{\text {norm }}$ (Fig. 3), white indicates contacts with distances equal to the sum of van der Waals radii, while red and blue indicate distances shorter (in close contact) or longer (distinct contact) than the van der Waals radii, respectively (Venkatesan et al., 2016). The bright-red spots appearing near $\mathrm{O} 1, \mathrm{O} 6, \mathrm{~N} 2$ and hydrogen atoms $\mathrm{H} 2, \mathrm{H} 7 A$, $\mathrm{H} 7 \mathrm{~B}$ indicate their roles as the respective donors and/or acceptors. The shape-index of the HS is a tool to visualize the $\pi-\pi$ stacking by the presence of adjacent red and blue triangles; if these are absent, then there are no $\pi-\pi$ interactions. Fig. 4 clearly suggest that there are no $\pi-\pi$ interactions in (I). The overall two-dimensional fingerprint plot, Fig. $5 a$, and those delineated into $\mathrm{H} \cdots \mathrm{H}, \mathrm{H} \cdots \mathrm{C} / \mathrm{C} \cdots \mathrm{H}, \mathrm{H} \cdots \mathrm{O} / \mathrm{O} \cdots \mathrm{H}$, $\mathrm{H} \cdots \mathrm{N} / \mathrm{N} \cdots \mathrm{H}, \mathrm{C} \cdots \mathrm{C}$ and $\mathrm{C} \cdots \mathrm{N} / \mathrm{N} \cdots \mathrm{C}$ contacts (McKinnon et al., 2007) are illustrated in Fig. 5b-g, respectively, together with their relative contributions to the Hirshfeld surface. Selected contacts are listed in Table 2.

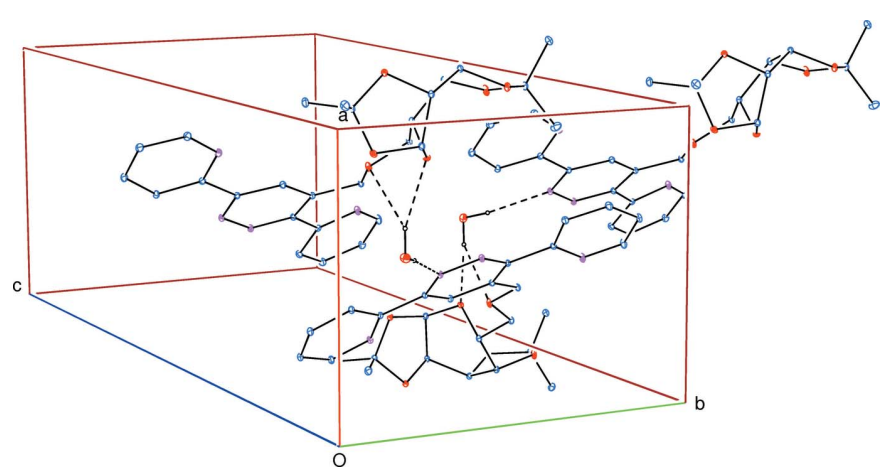

Figure 2

A partial packing diagram showing the $\mathrm{O}-\mathrm{H}_{\text {water }} \cdots \mathrm{O}_{\text {pyran }}, \mathrm{O}-$

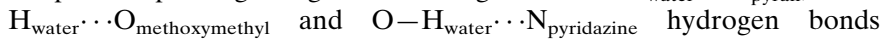
(Table 1) as dashed lines. 


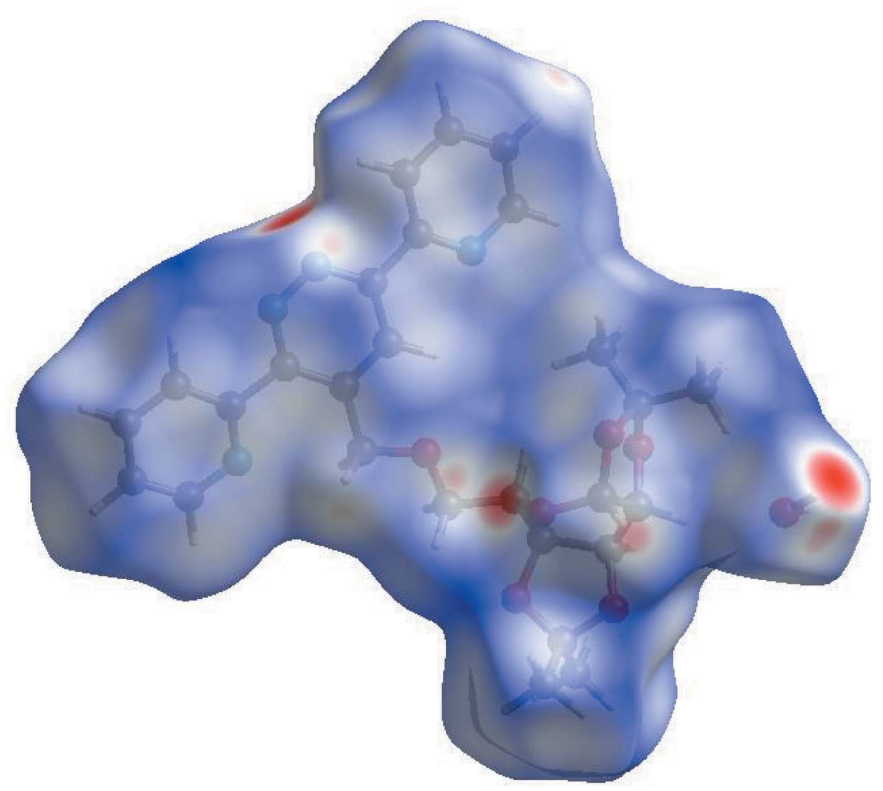

Figure 3

View of the three-dimensional Hirshfeld surface of the title compound plotted over $d_{\text {norm }}$ in the range -0.4555 to 1.4860 a.u.

The most important interaction is $\mathrm{H} \cdots \mathrm{H}$, contributing $55.7 \%$ to the overall crystal packing, which is reflected in Fig. $5 b$ as widely scattered points of high density due to the large hydrogen content of the molecule with the tip at $d_{\mathrm{e}}=d_{\mathrm{i}}$ $\sim 1.00 \AA$. In the presence of a weak $\mathrm{C}-\mathrm{H} \cdots \pi$ interaction, the wings in the fingerprint plot delineated into $\mathrm{H} \cdots \mathrm{C} / \mathrm{C} \cdots \mathrm{H}$ contacts $(14.6 \%$ contribution to the HS) have a symmetrical distribution of points, Fig. $5 c$, with the thin and thick edges at $d_{\mathrm{e}}+d_{\mathrm{i}}=2.85$ and $2.78 \AA$. The pair of characteristic wings in the fingerprint plot delineated into $\mathrm{H} \cdots \mathrm{O} / \mathrm{O} \cdots \mathrm{H}$ contacts $(14.5 \%$, Fig. $5 d$ ) arises from the $\mathrm{O}-\mathrm{H} \cdots \mathrm{O}$ and $\mathrm{C}-\mathrm{H} \cdots \mathrm{O}$ hydrogen bonds (Table 1) as well as from the $\mathrm{H} \cdots \mathrm{O} / \mathrm{O} \cdots \mathrm{H}$ contacts

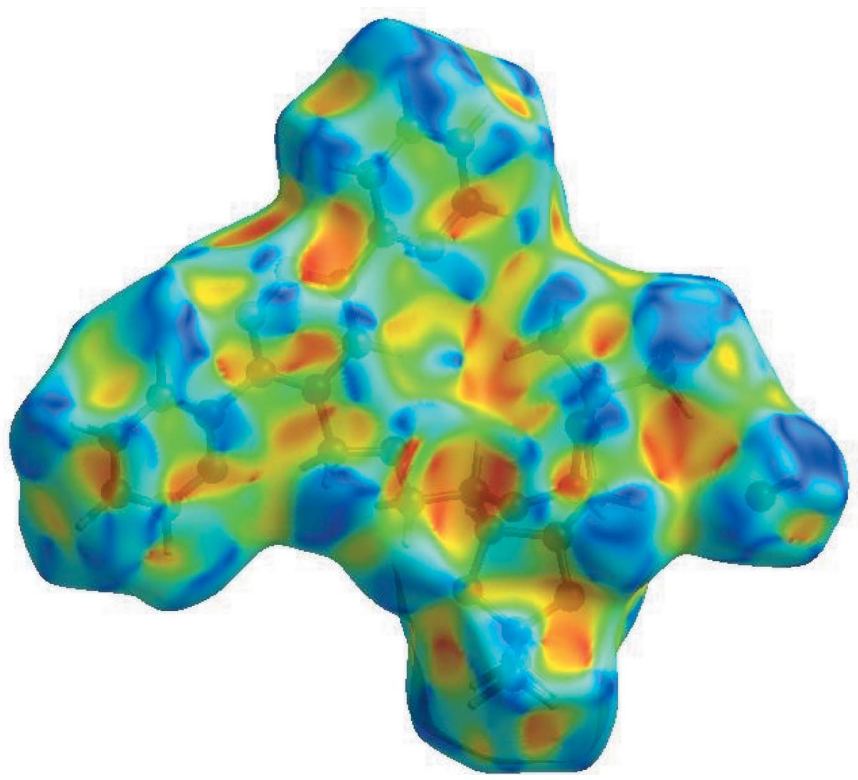

Figure 4

Hirshfeld surface of the title compound plotted over shape-index.
Table 2

Selected interatomic distances $(\AA)$.

\begin{tabular}{llll}
\hline $\mathrm{O} 1 \cdots \mathrm{O} 3$ & $3.153(2)$ & $\mathrm{C} 2 \cdots \mathrm{C} 4^{\mathrm{ii}}$ & $3.538(4)$ \\
$\mathrm{O} 1 \cdots \mathrm{O} 4$ & $3.115(3)$ & $\mathrm{C} 2 \cdots \mathrm{H} 4^{\mathrm{ii}}$ & 2.96 \\
$\mathrm{O} 1 \cdots \mathrm{O} 5$ & $2.999(3)$ & $\mathrm{C} 3 \cdots \mathrm{H} 1$ & 2.88 \\
$\mathrm{O} 1 \cdots \mathrm{O} 6$ & $2.920(3)$ & $\mathrm{C} 4 \cdots \mathrm{H} 11 A$ & 2.84 \\
$\mathrm{O} 3 \cdots \mathrm{O} 1$ & $3.153(2)$ & $\mathrm{C} 4 \cdots \mathrm{H} 2^{\mathrm{iii}}$ & 2.83 \\
$\mathrm{O} 3 \cdots \mathrm{C} 1$ & $3.002(3)$ & $\mathrm{C} 4 \cdots \mathrm{H} 1$ & 2.76 \\
$\mathrm{O} 7 \cdots \mathrm{O} 1$ & $3.112(3)$ & $\mathrm{C} 5 \cdots \mathrm{H} 9 A$ & 2.85 \\
$\mathrm{O} 7 \cdots \mathrm{O} 6$ & $3.176(3)$ & $\mathrm{C} 10 \cdots \mathrm{H} 1$ & 2.93 \\
$\mathrm{O} 7 \cdots \mathrm{N} 2^{\mathrm{i}}$ & $3.020(3)$ & $\mathrm{H} 1 \cdots \mathrm{H} 10 C$ & 2.24 \\
$\mathrm{O} 2 \cdots \mathrm{H} 1$ & 2.70 & $\mathrm{H} 2 \cdots \mathrm{H} 4^{\mathrm{ii}}$ & 2.44 \\
$\mathrm{O} 2 \cdots \mathrm{H} 4^{\mathrm{ii}}$ & 2.90 & $\mathrm{H} 4 \cdots \mathrm{H} 11 A$ & 2.47 \\
$\mathrm{O} 3 \cdots \mathrm{H} 1$ & 2.54 & $\mathrm{H} 5 \cdots \mathrm{H} 9 A$ & 2.56 \\
$\mathrm{O} 3 \cdots \mathrm{H} 2^{\mathrm{iii}}$ & 2.51 & $\mathrm{H} 7 A \cdots \mathrm{H} 19^{\mathrm{i}}$ & 2.20 \\
$\mathrm{O} 5 \cdots \mathrm{H} 12 B$ & 2.70 & $\mathrm{H} 7 A \cdots \mathrm{N} 1^{\mathrm{i}}$ & $2.84(3)$ \\
$\mathrm{O} 5 \cdots \mathrm{H} 12 A$ & 2.77 & $\mathrm{H} 7 A \cdots \mathrm{N} 2^{\mathrm{i}}$ & $2.19(4)$ \\
$\mathrm{O} 6 \cdots \mathrm{H} 17$ & 2.23 & $\mathrm{H} 7 B \cdots \mathrm{O} 1$ & $2.30(2)$ \\
$\mathrm{O} 7 \cdots \mathrm{H} 19^{\mathrm{i}}$ & 2.64 & $\mathrm{H} 7 B \cdots \mathrm{O} 6$ & $2.56(4)$ \\
$\mathrm{N} 4 \cdots \mathrm{C} 13$ & $2.776(3)$ & $\mathrm{H} 8 A \cdots \mathrm{H} 9 C$ & 2.55 \\
$\mathrm{~N} 1 \cdots \mathrm{H} 24$ & 2.44 & $\mathrm{H} 8 B \cdots \mathrm{H} 9 B$ & 2.50 \\
$\mathrm{~N} 2 \cdots \mathrm{H} 19$ & 2.56 & $\mathrm{H} 8 C \cdots \mathrm{H} 11 C^{\mathrm{ii}}$ & 2.48 \\
$\mathrm{~N} 3 \cdots \mathrm{H} 17$ & 2.46 & $\mathrm{H} 10 A \cdots \mathrm{H} 11 C$ & 2.53 \\
$\mathrm{~N} 4 \cdots \mathrm{H} 13 A$ & 2.56 & $\mathrm{H} 10 B \cdots \mathrm{H} 11 B$ & 2.57 \\
$\mathrm{~N} 4 \cdots \mathrm{H} 13 B$ & 2.54 & $\mathrm{H} 12 A \cdots \mathrm{H} 13 B$ & 2.26 \\
$\mathrm{C} 1 \cdots \mathrm{C} 3$ & $3.485(3)$ & & \\
\hline
\end{tabular}

Symmetry codes: (i) $\quad-x, y-\frac{1}{2},-z+\frac{1}{2} ; \quad$ (ii) $\quad x-\frac{1}{2},-y+\frac{1}{2},-z+1$; $x+\frac{1}{2},-y+\frac{1}{2},-z+1$.

(Table 2) and has a pair of spikes with the tips at $d_{\mathrm{e}}+d_{\mathrm{i}}=$ $2.18 \AA$. The pair of characteristic wings in the fingerprint plot delineated into $\mathrm{H} \cdots \mathrm{N} / \mathrm{N} \cdots \mathrm{H}$ contacts (Fig. $5 e, 9.6 \%$ ) arises from the $\mathrm{O}-\mathrm{H} \cdots \mathrm{N}$ hydrogen bonds (Table 1) as well as from the $\mathrm{H} \cdots \mathrm{N} / \mathrm{N} \cdots \mathrm{H}$ contacts has a pair of spikes with the tips at
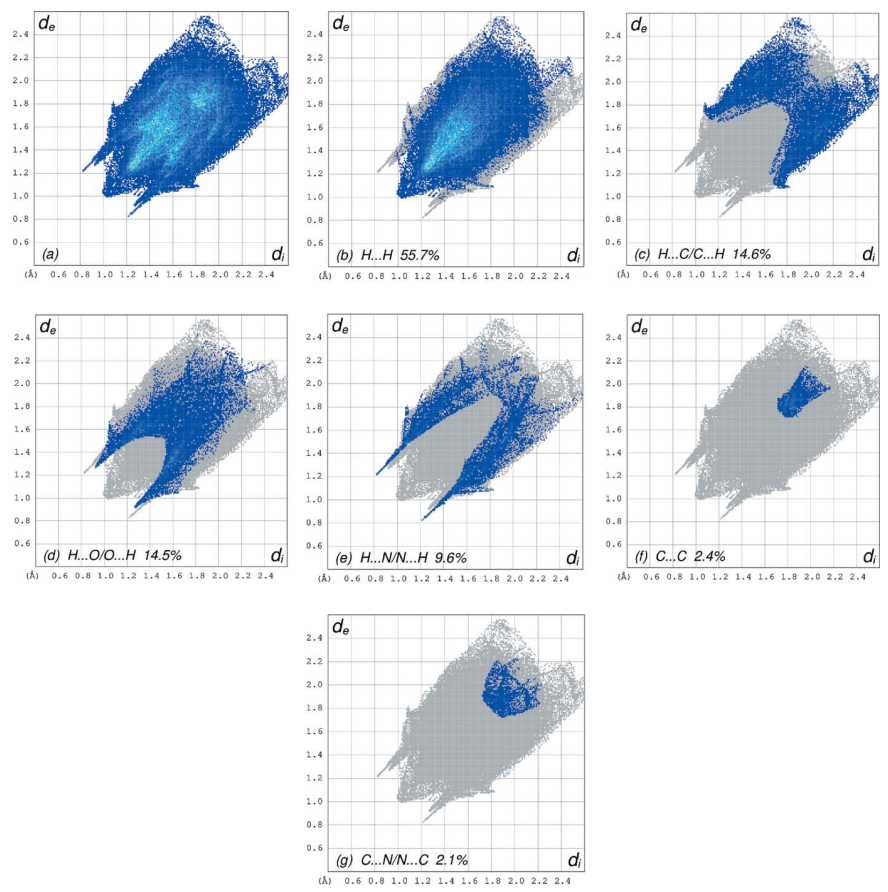

Figure 5

The full two-dimensional fingerprint plots for the title compound, showing (a) all interactions, and delineated into $(b) \mathrm{H} \cdots \mathrm{H},(c) \mathrm{H} \cdots \mathrm{C} /$ $\mathrm{C} \cdots \mathrm{H},(d) \mathrm{H} \cdots \mathrm{O} / \mathrm{O} \cdots \mathrm{H},(e) \mathrm{H} \cdots \mathrm{N} / \mathrm{N} \cdots \mathrm{H},(f) \mathrm{C} \cdots \mathrm{C}$ and $(g) \mathrm{C} \cdots \mathrm{N} /$ $\mathrm{N} \cdots \mathrm{C}$ interactions. The $d_{\mathrm{i}}$ and $d_{\mathrm{e}}$ values are the closest internal and external distances (in $\AA$ ) from given points on the Hirshfeld surface. 


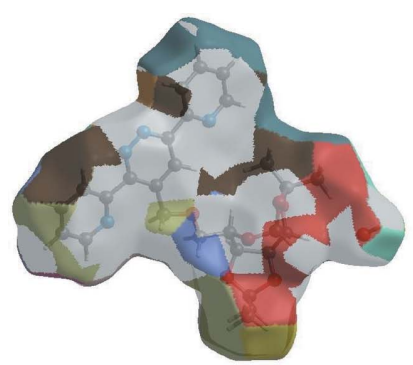

(a)

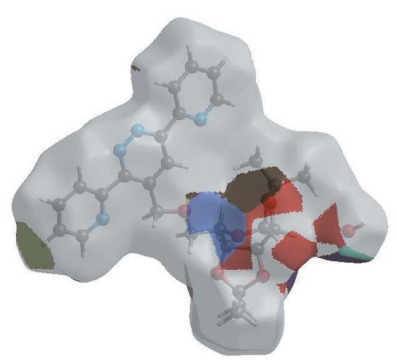

(c)

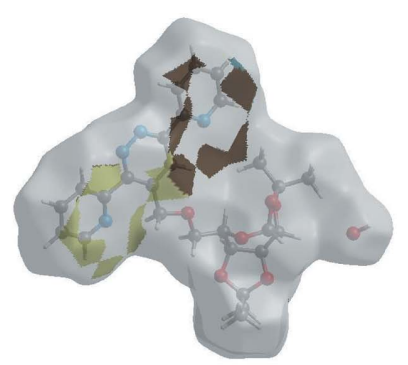

(b)

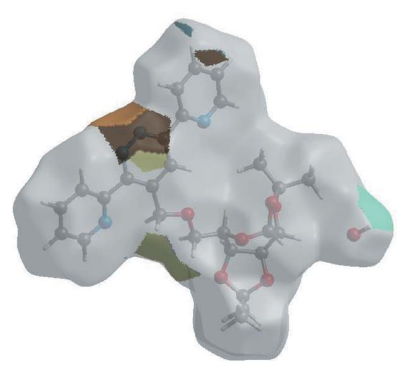

(d)
Figure 6

Hirshfeld surface representations with the function $d_{\text {norm }}$ plotted onto the surface for $(a) \mathrm{H} \cdots \mathrm{H},(b) \mathrm{H} \cdots \mathrm{C} / \mathrm{C} \cdots \mathrm{H},(c) \mathrm{H} \cdots \mathrm{O} / \mathrm{O} \cdots \mathrm{H}$ and $(d) \mathrm{H} \cdots \mathrm{N} /$ $\mathrm{N} \cdots \mathrm{H}$ interactions.

$d_{\mathrm{e}}+d_{\mathrm{i}}=2.04 \AA$. Finally, the C. . C contacts (Fig. 5g, 2.4\%) have a wide spike with the tip at $d_{\mathrm{e}}=d_{\mathrm{i}}=1.75 \AA$.

The Hirshfeld surface representations with the function $d_{\text {norm }}$ plotted onto the surface are shown for the $\mathrm{H} \cdots \mathrm{H}$, $\mathrm{H} \cdots \mathrm{C} / \mathrm{C} \cdots \mathrm{H}, \mathrm{H} \cdots \mathrm{O} / \mathrm{O} \cdots \mathrm{H}$ and $\mathrm{H} \cdots \mathrm{N} / \mathrm{N} \cdots \mathrm{H}$ interactions in Fig. $6 a-d$, respectively.

The Hirshfeld surface analysis confirms the importance of $\mathrm{H}$-atom contacts in establishing the packing. The large number of $\mathrm{H} \cdots \mathrm{H}, \mathrm{H} \cdots \mathrm{C} / \mathrm{C} \cdots \mathrm{H}, \mathrm{H} \cdots \mathrm{O} / \mathrm{O} \cdots \mathrm{H}$ and $\mathrm{H} \cdots \mathrm{N} / \mathrm{N} \cdots \mathrm{H}$ interactions suggest that van der Waals interactions and hydrogen bonding play the major roles in the crystal packing (Hathwar et al., 2015).

\section{Electrochemical measurements}

The effect of the title compound as an inhibitor of the corrosion of mild steel (MS) were studied using electrochemical impedance spectroscopy in the concentration range of $10^{-6}$ to $10^{-3} \mathrm{M}$ at $308 \mathrm{~K}$. The electrochemical experiment consisted of a 3 electrode electrolytic cell consisting of platinum foil as counter-electrode, saturated calomel as reference electrode and MS as working electrode with an exposed area of $1 \mathrm{~cm}^{2}$. The MS specimen was immersed in a test solution for $0.5 \mathrm{~h}$ until a steady-state potential was achieved using a PGZ100 potentiostat (Bouayad et al., 2018). Electrochemical impedance spectroscopy (EIS) measurements were performed over a frequency range of $0.1 \times 10^{-3}$ $\mathrm{KHz}$ to $10 \mathrm{mHz}$ and an amplitude of $10 \mathrm{mV}$ with 10 points per decade. The percentage inhibition efficiency is calculated from $R_{\mathrm{t}}$ values as (Sikine et al., 2016) $E(\%)=\left[1-R_{\mathrm{t}(\mathrm{HCl})} / \mathrm{R}_{\mathrm{t}(\mathrm{inh})}\right] \times$ 100 , where $R_{\mathrm{t}(\mathrm{inh})}$ and $R_{\mathrm{t}(\mathrm{HCl})}$ are the charge-transfer resistances for MS immersed in $\mathrm{HCl}$, with the title compound and

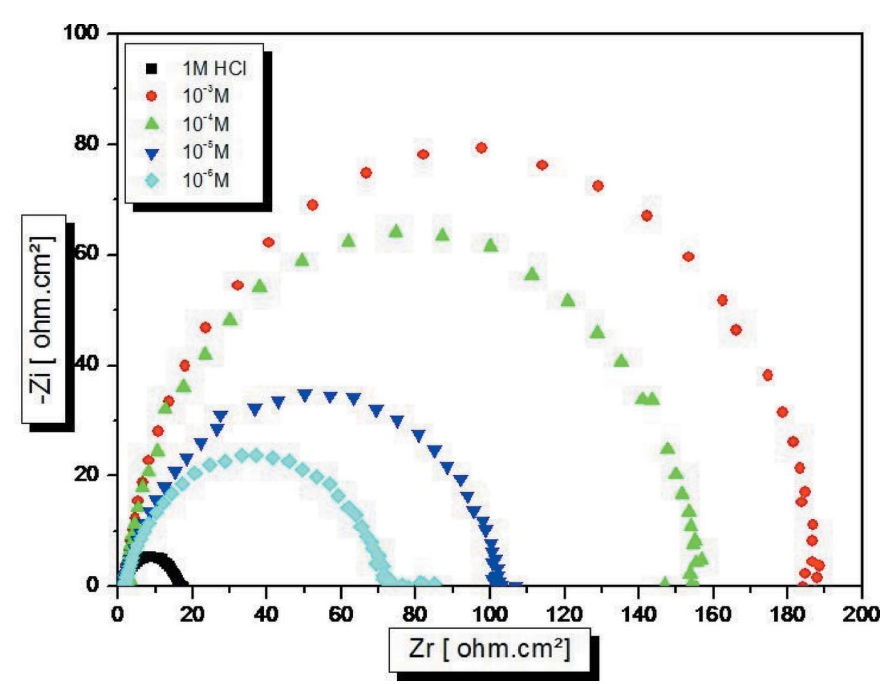

Figure 7

Nyquist plots of mild steel in $1 M \mathrm{HCl}$ in presence of different concentrations of 3,6-bis(pyridin-2-yl)-4- $\{[(3 \mathrm{a} S, 5 S, 5 \mathrm{a} R, 8 \mathrm{a} R, 8 \mathrm{~b} S)-2,2,7,7-$

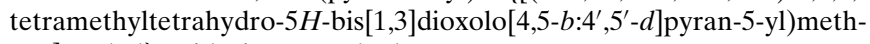
oxy]methyl\}pyridazine monohydrate.

without inhibitor. Nyquist representations of mild steel in $1 M$ $\mathrm{HCl}$ in the absence and presence of the inhibitor system are shown in Fig. 7.

The impedance method provides information about the kinetics of the electrode processes and the surface properties of the investigated systems. The technique is based on the measurement of the impedance of the double layer at the MS/ solution interface, and represents the Nyquist plots of mild steel (MS) specimens in $1 \mathrm{M} \mathrm{HCl}$ without and with various concentrations of the inhibitor. The impedance diagrams obtained have an almost semicircular appearance. This indicates that the corrosion of mild steel in aqueous solution is mainly controlled by a charge-transfer process. The impedance parameters are given in Fig. 8. It is observed from the

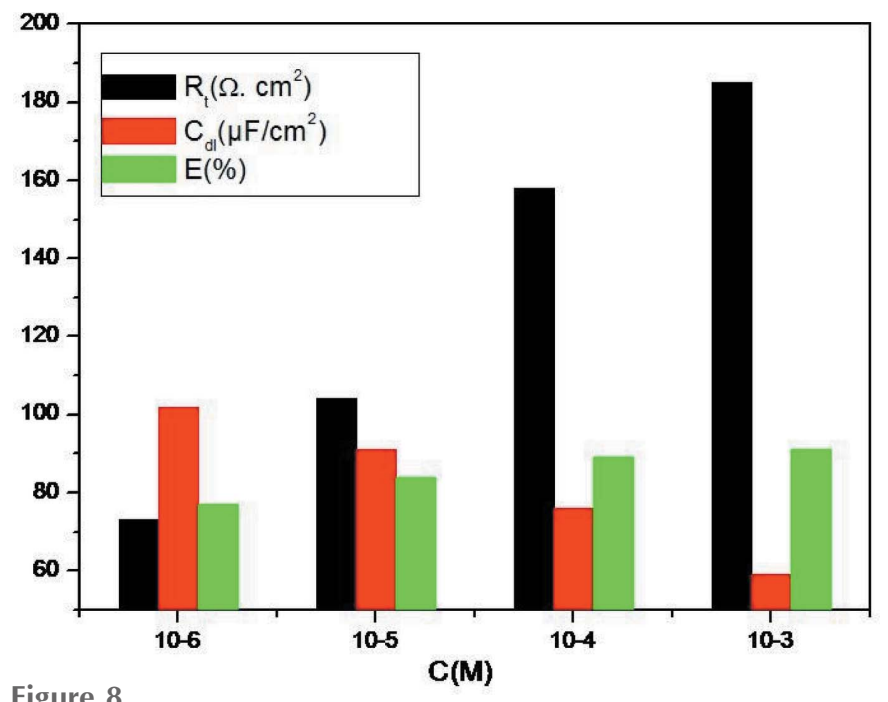

Figure 8

EIS parameters for the corrosion of mild steel in $1 M \mathrm{HCl}$ with and without inhibitor 3,6-bis(pyridin-2-yl)-4-\{[(3a $S, 5 S, 5 \mathrm{a} R, 8 \mathrm{a} R, 8 \mathrm{~b} S)-2,2,7,7$ -

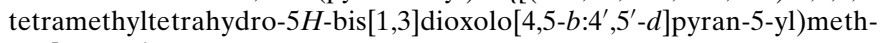
oxy]methyl\}pyridazine monohydrate at $308 \mathrm{~K}$. 
Table 3

Experimental details.

\begin{tabular}{|c|c|}
\hline \multicolumn{2}{|l|}{ Crystal data } \\
\hline Chemical formula & $\mathrm{C}_{27} \mathrm{H}_{30} \mathrm{~N}_{4} \mathrm{O}_{6} \cdot \mathrm{H}_{2} \mathrm{O}$ \\
\hline$M_{\mathrm{r}}$ & 524.56 \\
\hline Crystal system, space group & Orthorhombic, $P 2_{1} 2_{1} 2_{1}$ \\
\hline Temperature $(\mathrm{K})$ & 150 \\
\hline$a, b, c(\AA)$ & 8.8417 (3), $11.3252(3), 25.7003(8)$ \\
\hline$V\left(\AA^{3}\right)$ & $2573.47(14)$ \\
\hline$Z$ & 4 \\
\hline Radiation type & $\mathrm{Cu} K \alpha$ \\
\hline$\mu\left(\mathrm{mm}^{-1}\right)$ & 0.82 \\
\hline Crystal size (mm) & $0.47 \times 0.15 \times 0.10$ \\
\hline \multicolumn{2}{|l|}{ Data collection } \\
\hline Diffractometer & $\begin{array}{l}\text { Rigaku Oxford Diffraction Super- } \\
\text { Nova, single source at offset, } \\
\text { AtlasS2 }\end{array}$ \\
\hline Absorption correction & $\begin{array}{l}\text { Multi-scan (CrysAlis PRO (Rigaku } \\
\text { OD, 2015) }\end{array}$ \\
\hline$T_{\min }, T_{\max }$ & $0.656,1.000$ \\
\hline $\begin{array}{l}\text { No. of measured, independent and } \\
\text { observed }[I>2 \sigma(I)] \text { reflections }\end{array}$ & $6128,4277,3853$ \\
\hline$R_{\text {int }}$ & 0.037 \\
\hline$(\sin \theta / \lambda)_{\max }\left(\AA^{-1}\right)$ & 0.618 \\
\hline \multicolumn{2}{|l|}{ Refinement } \\
\hline$R\left[F^{2}>2 \sigma\left(F^{2}\right)\right], w R\left(F^{2}\right), S$ & $0.048,0.121,1.10$ \\
\hline No. of reflections & 4277 \\
\hline No. of parameters & 353 \\
\hline No. of restraints & 2 \\
\hline $\mathrm{H}$-atom treatment & $\begin{array}{l}\mathrm{H} \text { atoms treated by a mixture of } \\
\text { independent and constrained } \\
\text { refinement }\end{array}$ \\
\hline$\Delta \rho_{\max }, \Delta \rho_{\min }\left(\mathrm{e} \AA^{-3}\right)$ & $0.27,-0.36$ \\
\hline Absolute structure & $\begin{array}{l}\text { Flack } x \text { determined using } 1226 \\
\quad \text { quotients }\left[\left(I^{+}\right)-\left(I^{-}\right)\right] /\left[\left(I^{+}\right)+\left(I^{-}\right)\right] \\
\quad \text { (Parsons et al., 2013) }\end{array}$ \\
\hline Absolute structure parameter & $-0.01(16)$ \\
\hline
\end{tabular}

Computer programs: CrysAlis PRO (Rigaku OD, 2015), SHELXS97 (Sheldrick, 2008), SHELXL2018 (Sheldrick, 2015), ORTEP-3 for Windows and Win GX (Farrugia, 2012) and PLATON (Spek, 2015).

plots that the impedance response of mild steel was significantly changed after addition of the inhibitor. $R_{\mathrm{ct}}$ is increased to a maximum value of $185 \Omega \mathrm{cm}^{2}$ for the inhibitor, showing a maximum inhibition efficiency of $91 \%$ at $10^{-3} \mathrm{M}$. The decrease in $C_{\mathrm{dl}}$ from the $\mathrm{HCl}$ acid value of $200 \mu \mathrm{F} \mathrm{cm}^{-2}$, may be due to the increase in the thickness of the electrical double layer or to a decrease in the local dielectric constant (Elmsellem et al., 2014). This is caused by the gradual displacement of water molecules by the adsorption of organic molecules on the mild steel surface (Hjouji et al., 2016). Apart from the experimental impedance (EIS) results, the following conclusion is drawn: the alternating impedance spectrum reveals that the double-layer capacitances decrease with respect to the blank solution when the title compound is added. This fact confirms the adsorption of inhibitor molecules on the surface of the MS.

\section{Database survey}

Silver(I) complexes coordinated by 3,6-di(pyridin-2-yl)pyridazine ligands have been reported (Constable et al., 2008). Three other metal complexes including 3,6-di(pyridin-2- yl)pyridazine have also been reported, viz. aquabis[3,6-bis(pyridin-2-yl)pyridazine- $\left.\kappa_{2} N^{1}, N^{6}\right]$ copper(II) bis(trifluoromethanesulfonate) (Showrilu et al., 2017), tetrakis $[\mu-3,6-$ di(pyridin-2-yl)pyridazine]bis( $\mu$-hydroxo)bis( $\mu$-aqua)tetranickel(II) hexakis(nitrate) tetradecahydrate (Marino et al., 2019) and catena-[[ $\mu^{2}-3,6-\operatorname{di}($ pyridin-2-yl)pyridazine $]$ bis $\left(\mu^{2}-\right.$ azido)diazaidodicopper monohydrate] (Mastropietro et al., 2013).

\section{Synthesis and crystallization}

6- $O$-Propargyl-1,2:3,4-di- $O$-isopropylidene- $\alpha$-D-galactopyranoside (4 mmol) was added to a solution of 3,6-bis(2-pyridyl)1,2,4,5-tetrazine $(4 \mathrm{mmol})$ in toluene $(20 \mathrm{ml})$. Stirring was continued at room temperature for $4 \mathrm{~h}$. The solvent was removed under reduced pressure. The residue was separated by chromatography on a column of silica gel with ethyl acetate/hexane (1:2) as eluent. Colourless crystals were isolated on evaporation of the solvent (yield: $82 \%$ ).

\section{Refinement}

Crystal data, data collection and structure refinement details are summarized in Table 3. Water hydrogen atoms were located in a difference-Fourier map and refined with the distance constraint $\mathrm{O}-\mathrm{H}=0.80$ (2) $\AA$. Other $\mathrm{H}$ atoms were positioned geometrically with $\mathrm{C}-\mathrm{H}=0.93,0.98,0.97$ and $0.96 \AA$, for aromatic, methine, methylene and methyl $\mathrm{H}$ atoms, respectively, and constrained to ride on their parent atoms, with $U_{\text {iso }}(\mathrm{H})=1.5 U_{\text {eq }}(\mathrm{C}$-methyl $)$ or $1.2 U_{\text {eq }}(\mathrm{C})$ for all other $\mathrm{H}$ atoms.

\section{Funding information}

$\mathrm{TH}$ is grateful to Hacettepe University Scientific Research Project Unit (grant No. 013 D04 602 004).

\section{References}

Bouayad, K., Kandri Rodi, Y., Elmsellem, H., El Ghadraoui, E. H., Ouzidan, Y., Abdel-Rahman, I., Kusuma, H. S., Warad, I., Mague, J. T., Essassi, E. M., Hammouti, B. \& Chetouani, A. (2018). Mor. J. Chem. 6, 22-34.

Constable, E. C., Housecroft, C. E., Neuburger, M., Reymann, S. \& Schaffner, S. (2008). Aust. J. Chem. 61, 847-853.

Elmsellem, H., Nacer, H., Halaimia, F., Aouniti, A., Lakehal, I., Chetouani, A., Al-Deyab, S. S., Warad, I., Touzani, R. \& Hammouti, B. (2014). Int. J. Electrochem. Sci. 9, 5328-5351.

Farrugia, L. J. (2012). J. Appl. Cryst. 45, 849-854.

Hathwar, V. R., Sist, M., Jørgensen, M. R. V., Mamakhel, A. H., Wang, X., Hoffmann, C. M., Sugimoto, K., Overgaard, J. \& Iversen, B. B. (2015). IUCrJ, 2, 563-574.

Hirshfeld, H. L. (1977). Theor. Chim. Acta, 44, 129-138.

Hjouji, M. Y., Djedid, M., Elmsellem, H., Kandri Rodi, Y., Ouzidan, Y., Ouazzani Chahdi, F., Sebbar, N. K., Essassi, E. M., AbdelRahman, I. \& Hammouti, B. (2016). J. Mater. Environ. Sci. 7, 14251435.

Kaim, W. \& Kohlmann, S. (1987). Inorg. Chem. 26, 68-77.

Khadiri, A., Saddik, R., Bekkouche, K., Aouniti, A., Hammouti, B., Benchat, N., Bouachrine, M. \& Solmaz, R. (2016). J. Taiwan Inst. Chem. Eng. 58, 552-564. 
Kore, A. R., Yang, B. \& Srinivasan, B. (2015). Tetrahedron Lett. 56, 808-811.

Marino, N., Bruno, R., Bentama, A., Pascual-Álvarez, A., Lloret, F., Julve, M. \& De Munno, G. (2019). CrystEngComm, 21, 917-924.

Mastropietro, T. F., Marino, N., Armentano, D., De Munno, G., Yuste, C., Lloret, F. \& Julve, M. (2013). Cryst. Growth Des. 13, 270-281.

McKinnon, J. J., Jayatilaka, D. \& Spackman, M. A. (2007). Chem. Commun. 3814-3816.

Parsons, S., Flack, H. D. \& Wagner, T. (2013). Acta Cryst. B69, 249259.

Rigaku OD (2015). CrysAlis PRO. Rigaku Oxford Diffraction, Yarnton, England.

Sheldrick, G. M. (2008). Acta Cryst. A64, 112-122.

Sheldrick, G. M. (2015). Acta Cryst. C71, 3-8.
Showrilu, K., Rajarajan, K., Martin Britto Dhas, S. A. \& Athimoolam, S. (2017). IUCrData, 2, x171142.

Sikine, M., Elmsellem, H., Kandri Rodi, Y., Steli, H., Aouniti, A., Hammouti, B., Ouzidan, Y., Ouazzani Chahdi, F., Bourass, M. \& Essassi, E. M. (2016). J. Mater. Environ. Sci. 7, 4620-4632.

Spackman, M. A. \& Jayatilaka, D. (2009). CrystEngComm, 11, 19-32. Spek, A. L. (2015). Acta Cryst. C71, 9-18.

Tsukada, N., Sato, T., Mori, H., Sugawara, S., Kabuto, C., Miyano, S. \& Inoue, Y. (2001). J. Organomet. Chem. 627, 121-126.

Turner, M. J., McKinnon, J. J., Wolff, S. K., Grimwood, D. J., Spackman, P. R., Jayatilaka, D. \& Spackman, M. A. (2017). CrystalExplorer17. The University of Western Australia.

Venkatesan, P., Thamotharan, S., Ilangovan, A., Liang, H. \& Sundius, T. (2016). Spectrochim. Acta Part A, 153, 625-636. 


\section{supporting information}

Acta Cryst. (2019). E75, 1169-1174［https://doi.org/10.1107/S2056989019009848]

Crystal structure, Hirshfeld surface analysis and corrosion inhibition study of 3,6-bis(pyridin-2-yl)-4-\{[(3aS,5S,5aR,8aR,8bS)-2,2,7,7-tetramethyltetrahydro-5H-bis[1,3]dioxolo[4,5-b:4',5'-d] pyran-5-yl)methoxy]methyl\}pyridazine monohydrate

Mouad Filali, Hicham Elmsellem, Tuncer Hökelek, Abdelkrim El-Ghayoury, Oleh Stetsiuk, EI Mestafa El Hadrami and Abdessalam Ben-Tama

Computing details

Data collection: CrysAlis PRO (Rigaku OD, 2015); cell refinement: CrysAlis PRO (Rigaku OD, 2015); data reduction: CrysAlis PRO (Rigaku OD, 2015); program(s) used to solve structure: SHELXS97 (Sheldrick, 2008); program(s) used to refine structure: SHELXL2018 (Sheldrick, 2015); molecular graphics: ORTEP-3 for Windows (Farrugia, 2012) and PLATON (Spek, 2015); software used to prepare material for publication: WinGX (Farrugia, 2012) and PLATON (Spek, 2015).

3,6-Bis(pyridin-2-yl)-4-\{[(3aS,5S,5aR,8aR,8bS)-2,2,7,7-tetramethyltetrahydro-5H-bis[1,3]dioxolo[4,5-b:4',5'$d$ ]pyran-5-yl)methoxy]methyl\}pyridazine monohydrate

Crystal data

$\mathrm{C}_{27} \mathrm{H}_{30} \mathrm{~N}_{4} \mathrm{O}_{6} \cdot \mathrm{H}_{2} \mathrm{O}$

$M_{r}=524.56$

Orthorhombic, $P 2_{1} 2_{1} 2_{1}$

$a=8.8417$ (3) $\AA$

$b=11.3252(3) \AA$

$c=25.7003(8) \AA$

$V=2573.47(14) \AA^{3}$

$Z=4$

$F(000)=1112$

$D_{\mathrm{x}}=1.354 \mathrm{Mg} \mathrm{m}^{-3}$

$\mathrm{Cu} K \alpha$ radiation, $\lambda=1.54184 \AA$

Cell parameters from 2843 reflections

$\theta=3.3-72.3^{\circ}$

$\mu=0.82 \mathrm{~mm}^{-1}$

$T=150 \mathrm{~K}$

Plate, colourless

$0.47 \times 0.15 \times 0.10 \mathrm{~mm}$

Data collection

Rigaku Oxford Diffraction SuperNova, single source at offset, AtlasS2 diffractometer

Radiation source: SuperNova(Cu) micro-focus sealed X-ray Source

Detector resolution: 5.1990 pixels $\mathrm{mm}^{-1}$

$\omega$ scans

Absorption correction: multi-scan (CrysAlis PRO (Rigaku OD, 2015)

$T_{\min }=0.656, T_{\max }=1.000$

6128 measured reflections

4277 independent reflections

3853 reflections with $I>2 \sigma(I)$

$R_{\text {int }}=0.037$

$\theta_{\max }=72.4^{\circ}, \theta_{\min }=3.4^{\circ}$

$h=-9 \rightarrow 10$

$k=-13 \rightarrow 5$

$l=-31 \rightarrow 29$ 


\section{Refinement}

Refinement on $F^{2}$

Least-squares matrix: full

$R\left[F^{2}>2 \sigma\left(F^{2}\right)\right]=0.048$

$w R\left(F^{2}\right)=0.121$

$S=1.10$

4277 reflections

353 parameters

2 restraints

Hydrogen site location: mixed
$\mathrm{H}$ atoms treated by a mixture of independent and constrained refinement

$w=1 /\left[\sigma^{2}\left(F_{\mathrm{o}}^{2}\right)+(0.0538 P)^{2}+0.4885 P\right]$

where $P=\left(F_{\mathrm{o}}^{2}+2 F_{\mathrm{c}}^{2}\right) / 3$

$(\Delta / \sigma)_{\max }<0.001$

$\Delta \rho_{\max }=0.27 \mathrm{e} \AA^{-3}$

$\Delta \rho_{\min }=-0.36$ e $\AA^{-3}$

Absolute structure: Flack $x$ determined using 1226 quotients $\left[\left(I^{+}\right)-(I)\right] /\left[\left(I^{+}\right)+(I)\right]$ (Parsons et al., 2013)

Absolute structure parameter: -0.01 (16)

\section{Special details}

Geometry. All esds (except the esd in the dihedral angle between two 1.s. planes) are estimated using the full covariance matrix. The cell esds are taken into account individually in the estimation of esds in distances, angles and torsion angles; correlations between esds in cell parameters are only used when they are defined by crystal symmetry. An approximate (isotropic) treatment of cell esds is used for estimating esds involving 1.s. planes.

Fractional atomic coordinates and isotropic or equivalent isotropic displacement parameters $\left(\AA^{2}\right)$

\begin{tabular}{|c|c|c|c|c|}
\hline & $x$ & $y$ & $z$ & $U_{\text {iso }} * / U_{\text {eq }}$ \\
\hline $\mathrm{O} 1$ & $0.3541(3)$ & $0.1622(2)$ & $0.41689(9)$ & $0.0282(5)$ \\
\hline $\mathrm{O} 2$ & $0.3948(3)$ & 0.34989 (19) & $0.45130(10)$ & $0.0314(5)$ \\
\hline $\mathrm{O} 3$ & $0.6462(3)$ & $0.30998(18)$ & $0.44345(9)$ & $0.0275(5)$ \\
\hline $\mathrm{O} 4$ & 0.5889 & 0.00085 (19) & $0.47272(8)$ & $0.0298(5)$ \\
\hline $\mathrm{O} 5$ & $0.5504(4)$ & -0.04337 (19) & $0.38768(10)$ & $0.0397(7)$ \\
\hline O6 & $0.2874(3)$ & $0.20336(19)$ & $0.30710(9)$ & $0.0341(6)$ \\
\hline N1 & $0.0414(3)$ & $0.4001(2)$ & $0.16743(11)$ & $0.0279(6)$ \\
\hline N2 & $0.0957(3)$ & $0.5016(2)$ & $0.18697(10)$ & $0.0280(6)$ \\
\hline N3 & $0.3589(4)$ & $0.6013(3)$ & $0.28330(11)$ & $0.0324(6)$ \\
\hline N4 & $0.0746(4)$ & $0.0864(2)$ & $0.17094(12)$ & $0.0358(7)$ \\
\hline $\mathrm{C} 1$ & $0.4587(4)$ & $0.1547(3)$ & $0.37413(12)$ & $0.0258(7)$ \\
\hline $\mathrm{H} 1$ & 0.495093 & 0.234348 & 0.366098 & $0.031 *$ \\
\hline $\mathrm{C} 2$ & $0.4106(4)$ & $0.2260(3)$ & $0.45945(13)$ & $0.0277(7)$ \\
\hline $\mathrm{H} 2$ & 0.355033 & 0.203400 & 0.490891 & $0.033 *$ \\
\hline $\mathrm{C} 3$ & $0.5408(4)$ & 0.4049 & $0.44788(14)$ & $0.0310(7)$ \\
\hline $\mathrm{C} 4$ & $0.5790(4)$ & $0.2100(3)$ & $0.46886(12)$ & $0.0246(6)$ \\
\hline H4 & 0.600843 & 0.212023 & 0.506234 & $0.030 *$ \\
\hline C5 & $0.6463(4)$ & 0.0999 (3) & $0.44448(12)$ & $0.0254(6)$ \\
\hline H5 & 0.756973 & 0.102135 & 0.446060 & $0.031 *$ \\
\hline C6 & $0.5926(4)$ & $0.0790(3)$ & $0.38885(12)$ & $0.0272(7)$ \\
\hline H6 & 0.676097 & 0.092996 & 0.364527 & $0.033 *$ \\
\hline $\mathrm{C} 7$ & $0.5754(4)$ & $-0.0947(3)$ & $0.43729(13)$ & $0.0310(7)$ \\
\hline $\mathrm{C} 8$ & $0.4413(5)$ & -0.1669 (4) & $0.4525(2)$ & $0.0550(12)$ \\
\hline H8A & 0.453499 & -0.194150 & 0.487614 & $0.082 *$ \\
\hline $\mathrm{H} 8 \mathrm{~B}$ & 0.432577 & -0.233440 & 0.429569 & $0.082 *$ \\
\hline $\mathrm{H} 8 \mathrm{C}$ & 0.351559 & -0.119463 & 0.450095 & $0.082 *$ \\
\hline C9 & $0.7193(5)$ & $-0.1667(3)$ & $0.43584(15)$ & $0.0394(9)$ \\
\hline H9A & 0.802843 & -0.116353 & 0.427016 & $0.059 *$ \\
\hline
\end{tabular}




\begin{tabular}{|c|c|c|c|c|}
\hline H9B & 0.709878 & -0.227881 & 0.410208 & $0.059^{*}$ \\
\hline $\mathrm{H} 9 \mathrm{C}$ & 0.736583 & -0.201467 & 0.469376 & $0.059^{*}$ \\
\hline $\mathrm{C} 10$ & $0.5503(5)$ & $0.4786(3)$ & $0.39910(15)$ & $0.0427(9)$ \\
\hline $\mathrm{H} 10 \mathrm{~A}$ & 0.650263 & 0.510885 & 0.395892 & $0.064 *$ \\
\hline H10B & 0.478045 & 0.541722 & 0.400967 & $0.064 *$ \\
\hline $\mathrm{H} 10 \mathrm{C}$ & 0.528653 & 0.430067 & 0.369395 & $0.064 *$ \\
\hline $\mathrm{C} 11$ & $0.5698(5)$ & 0.4759 (3) & $0.49680(16)$ & $0.0442(9)$ \\
\hline H11A & 0.569729 & 0.424125 & 0.526380 & $0.066^{*}$ \\
\hline H11B & 0.491803 & 0.534147 & 0.500856 & $0.066^{*}$ \\
\hline $\mathrm{H} 11 \mathrm{C}$ & 0.666221 & 0.514400 & 0.494189 & $0.066^{*}$ \\
\hline $\mathrm{C} 12$ & $0.3729(4)$ & $0.1086(3)$ & $0.32779(13)$ & $0.0286(7)$ \\
\hline $\mathrm{H} 12 \mathrm{~A}$ & 0.442659 & 0.078782 & 0.301797 & $0.034^{*}$ \\
\hline H12B & 0.306342 & 0.044768 & 0.338237 & $0.034^{*}$ \\
\hline $\mathrm{C} 13$ & $0.2122(4)$ & $0.1736(3)$ & $0.26014(13)$ & $0.0275(7)$ \\
\hline H13A & 0.122273 & 0.127514 & 0.267550 & $0.033^{*}$ \\
\hline H13B & 0.278292 & 0.127130 & 0.238042 & $0.033^{*}$ \\
\hline $\mathrm{C} 14$ & 0.1697 (4) & $0.2873(3)$ & $0.23325(12)$ & $0.0253(6)$ \\
\hline $\mathrm{C} 15$ & $0.0791(4)$ & 0.2958 (3) & $0.18820(12)$ & $0.0247(6)$ \\
\hline $\mathrm{C} 16$ & $0.1872(4)$ & $0.4980(3)$ & $0.22846(12)$ & $0.0247(6)$ \\
\hline $\mathrm{C} 17$ & 0.2238 & 0.3919 (3) & $0.25319(12)$ & $0.0263(6)$ \\
\hline H17 & 0.284224 & 0.391984 & 0.282822 & $0.032 *$ \\
\hline $\mathrm{C} 18$ & 0.2537 (4) & 0.6114 (3) & $0.24658(12)$ & $0.0265(7)$ \\
\hline C19 & 0.2107 (4) & 0.7197 (3) & $0.22546(14)$ & $0.0315(7)$ \\
\hline H19 & 0.135761 & 0.723846 & 0.200145 & $0.038^{*}$ \\
\hline $\mathrm{C} 20$ & $0.2823(5)$ & $0.8210(3)$ & $0.24304(15)$ & $0.0380(8)$ \\
\hline $\mathrm{H} 20$ & 0.256630 & 0.894499 & 0.229490 & $0.046^{*}$ \\
\hline $\mathrm{C} 21$ & $0.3920(4)$ & $0.8114(3)$ & $0.28088(15)$ & $0.0376(9)$ \\
\hline $\mathrm{H} 21$ & 0.441630 & 0.877961 & 0.293426 & $0.045^{*}$ \\
\hline $\mathrm{C} 22$ & $0.4265(5)$ & $0.7001(3)$ & $0.29975(14)$ & $0.0349(8)$ \\
\hline $\mathrm{H} 22$ & 0.500690 & 0.693707 & 0.325247 & $0.042 *$ \\
\hline $\mathrm{C} 23$ & 0.0175 (4) & 0.1927 (3) & $0.15887(12)$ & $0.0253(7)$ \\
\hline $\mathrm{C} 24$ & $-0.0897(4)$ & 0.2085 (3) & $0.12003(13)$ & $0.0325(7)$ \\
\hline $\mathrm{H} 24$ & -0.126828 & 0.283313 & 0.112401 & $0.039^{*}$ \\
\hline $\mathrm{C} 25$ & $-0.1402(5)$ & 0.1107 (3) & $0.09294(14)$ & $0.0378(8)$ \\
\hline $\mathrm{H} 25$ & -0.211674 & 0.119110 & 0.066653 & $0.045^{*}$ \\
\hline $\mathrm{C} 26$ & $-0.0836(5)$ & 0.0004 (3) & $0.10520(14)$ & $0.0375(8)$ \\
\hline $\mathrm{H} 26$ & -0.116014 & -0.066836 & 0.087656 & $0.045^{*}$ \\
\hline $\mathrm{C} 27$ & $0.0224(5)$ & -0.0065 & $0.14423(15)$ & $0.0414(9)$ \\
\hline $\mathrm{H} 27$ & 0.060342 & -0.080694 & 0.152640 & $0.050^{*}$ \\
\hline $\mathrm{O} 7$ & $0.0146(4)$ & $0.1893(3)$ & $0.38725(14)$ & $0.0542(8)$ \\
\hline H7A & $-0.011(7)$ & $0.141(5)$ & $0.3642(19)$ & $0.081^{*}$ \\
\hline H7B & $0.111(3)$ & $0.189(6)$ & $0.386(2)$ & $0.081^{*}$ \\
\hline
\end{tabular}

Atomic displacement parameters $\left(\AA^{2}\right)$

\begin{tabular}{lllllll}
\hline & $U^{11}$ & $U^{22}$ & $U^{33}$ & $U^{12}$ & $U^{13}$ & $U^{23}$ \\
\hline O1 & $0.0250(11)$ & $0.0272(10)$ & $0.0325(11)$ & $-0.0023(10)$ & $-0.0016(10)$ & $-0.0023(9)$ \\
O2 & $0.0294(12)$ & $0.0210(10)$ & $0.0438(13)$ & $0.0057(9)$ & $-0.0026(11)$ & $-0.0024(9)$
\end{tabular}




\begin{tabular}{|c|c|c|c|c|c|c|}
\hline $\mathrm{O} 3$ & $0.0280(11)$ & $0.0181(10)$ & $0.0364(12)$ & $0.0007(9)$ & $0.0010(10)$ & $0.0006(9)$ \\
\hline $\mathrm{O} 4$ & $0.0419(14)$ & $0.0190(9)$ & $0.0286(11)$ & $-0.0011(10)$ & $-0.0005(11)$ & $0.0020(8)$ \\
\hline O5 & $0.0627(18)$ & $0.0179(10)$ & $0.0385(13)$ & $0.0041(11)$ & $-0.0184(14)$ & $-0.0038(9)$ \\
\hline O6 & $0.0499(15)$ & $0.0190(9)$ & $0.0333(12)$ & $0.0033(11)$ & $-0.0182(12)$ & $-0.0023(9)$ \\
\hline N1 & $0.0324(15)$ & $0.0203(12)$ & $0.0310(13)$ & $-0.0004(11)$ & $-0.0037(13)$ & $-0.0002(10)$ \\
\hline $\mathrm{N} 2$ & $0.0339(16)$ & $0.0192(11)$ & $0.0310(13)$ & $0.0005(11)$ & $0.0006(13)$ & $-0.0010(10)$ \\
\hline N3 & $0.0367(16)$ & $0.0252(13)$ & $0.0352(14)$ & $-0.0026(12)$ & $-0.0011(13)$ & $-0.0045(11)$ \\
\hline N4 & $0.0485(18)$ & $0.0212(12)$ & $0.0377(15)$ & $0.0021(13)$ & $-0.0154(15)$ & $-0.0018(11)$ \\
\hline $\mathrm{C} 1$ & $0.0331(17)$ & $0.0180(12)$ & $0.0265(15)$ & $-0.0010(13)$ & $-0.0025(14)$ & $0.0020(11)$ \\
\hline $\mathrm{C} 2$ & $0.0333(17)$ & $0.0201(13)$ & $0.0298(15)$ & $0.0016(13)$ & $0.0036(15)$ & $-0.0006(12)$ \\
\hline $\mathrm{C} 3$ & $0.0324(18)$ & $0.0192(13)$ & $0.0415(18)$ & $0.0039(14)$ & $-0.0005(16)$ & $-0.0011(13)$ \\
\hline $\mathrm{C} 4$ & $0.0299(16)$ & $0.0179(12)$ & $0.0260(14)$ & $-0.0003(13)$ & $-0.0018(14)$ & $-0.0005(11)$ \\
\hline $\mathrm{C} 5$ & $0.0295(16)$ & $0.0188(13)$ & $0.0280(15)$ & $0.0026(13)$ & $0.0008(14)$ & $0.0019(12)$ \\
\hline C6 & $0.0333(18)$ & $0.0209(13)$ & $0.0274(15)$ & $0.0010(13)$ & $-0.0001(14)$ & $-0.0005(12)$ \\
\hline $\mathrm{C} 7$ & $0.0382(19)$ & $0.0194(13)$ & $0.0354(17)$ & $0.0006(14)$ & $-0.0015(16)$ & $-0.0004(12)$ \\
\hline C8 & $0.047(2)$ & $0.0365(19)$ & $0.081(3)$ & $-0.012(2)$ & $0.017(2)$ & $-0.020(2)$ \\
\hline C9 & $0.044(2)$ & $0.0321(17)$ & $0.042(2)$ & $0.0111(17)$ & $-0.0034(18)$ & $0.0023(15)$ \\
\hline $\mathrm{C} 10$ & $0.051(2)$ & $0.0257(16)$ & $0.051(2)$ & $0.0042(16)$ & $0.002(2)$ & $0.0079(15)$ \\
\hline $\mathrm{C} 11$ & $0.051(2)$ & $0.0317(17)$ & $0.050(2)$ & $0.0028(18)$ & $-0.007(2)$ & $-0.0124(16)$ \\
\hline $\mathrm{C} 12$ & $0.0360(18)$ & $0.0191(12)$ & $0.0307(15)$ & $0.0030(13)$ & $-0.0085(15)$ & $0.0024(12)$ \\
\hline $\mathrm{C} 13$ & $0.0331(17)$ & $0.0174(13)$ & $0.0319(16)$ & $-0.0019(13)$ & $-0.0062(14)$ & $0.0005(12)$ \\
\hline $\mathrm{C} 14$ & $0.0270(16)$ & $0.0224(14)$ & $0.0265(15)$ & $0.0009(13)$ & $-0.0004(13)$ & $0.0014(12)$ \\
\hline $\mathrm{C} 15$ & $0.0269(16)$ & $0.0194(13)$ & $0.0277(14)$ & $0.0000(13)$ & $-0.0005(14)$ & $-0.0013(12)$ \\
\hline $\mathrm{C} 16$ & $0.0265(16)$ & $0.0212(13)$ & $0.0265(14)$ & $-0.0003(12)$ & $0.0026(13)$ & $-0.0020(11)$ \\
\hline $\mathrm{C} 17$ & $0.0297(16)$ & $0.0220(13)$ & $0.0272(15)$ & $0.0006(13)$ & $-0.0020(14)$ & $-0.0011(12)$ \\
\hline $\mathrm{C} 18$ & $0.0285(16)$ & $0.0217(14)$ & $0.0293(15)$ & $-0.0001(12)$ & $0.0037(14)$ & $-0.0029(12)$ \\
\hline C19 & $0.0348(18)$ & $0.0208(14)$ & $0.0389(17)$ & $-0.0005(15)$ & $-0.0010(16)$ & $-0.0021(13)$ \\
\hline $\mathrm{C} 20$ & $0.043(2)$ & $0.0209(15)$ & $0.050(2)$ & $-0.0014(15)$ & $0.0039(18)$ & $-0.0021(14)$ \\
\hline $\mathrm{C} 21$ & $0.039(2)$ & $0.0247(15)$ & $0.049(2)$ & $-0.0039(14)$ & $0.0037(18)$ & $-0.0108(14)$ \\
\hline $\mathrm{C} 22$ & $0.0395(19)$ & $0.0276(15)$ & $0.0375(17)$ & $-0.0033(16)$ & $-0.0026(16)$ & $-0.0073(14)$ \\
\hline $\mathrm{C} 23$ & $0.0262(16)$ & $0.0238(14)$ & $0.0259(14)$ & $-0.0037(12)$ & $0.0008(13)$ & $0.0003(12)$ \\
\hline $\mathrm{C} 24$ & $0.0327(18)$ & $0.0295(15)$ & $0.0353(16)$ & $0.0029(15)$ & $-0.0075(15)$ & $-0.0002(14)$ \\
\hline $\mathrm{C} 25$ & $0.0383(19)$ & $0.0395(18)$ & $0.0358(18)$ & $-0.0010(17)$ & $-0.0148(17)$ & $-0.0026(15)$ \\
\hline $\mathrm{C} 26$ & $0.049(2)$ & $0.0271(15)$ & $0.0366(17)$ & $-0.0079(17)$ & $-0.0059(18)$ & $-0.0080(14)$ \\
\hline $\mathrm{C} 27$ & $0.058(3)$ & $0.0234(15)$ & $0.0428(19)$ & $0.0013(16)$ & $-0.015(2)$ & $-0.0027(15)$ \\
\hline $\mathrm{O} 7$ & $0.0524(18)$ & $0.0479(16)$ & $0.0623(19)$ & $0.0030(15)$ & $-0.0015(16)$ & $-0.0140(14)$ \\
\hline
\end{tabular}

Geometric parameters $\left(\AA,{ }^{\circ}\right)$

\begin{tabular}{llll}
\hline $\mathrm{O} 1-\mathrm{C} 2$ & $1.403(4)$ & $\mathrm{C} 9-\mathrm{H} 9 \mathrm{~B}$ & 0.9600 \\
$\mathrm{O} 1-\mathrm{C} 1$ & $1.439(4)$ & $\mathrm{C} 9-\mathrm{H} 9 \mathrm{C}$ & 0.9600 \\
$\mathrm{O} 2-\mathrm{C} 2$ & $1.425(4)$ & $\mathrm{C} 10-\mathrm{H} 10 \mathrm{~A}$ & 0.9600 \\
$\mathrm{O} 2-\mathrm{C} 3$ & $1.437(4)$ & $\mathrm{C} 10-\mathrm{H} 10 \mathrm{~B}$ & 0.9600 \\
$\mathrm{O} 3-\mathrm{C} 3$ & $1.428(4)$ & $\mathrm{C} 10-\mathrm{H} 10 \mathrm{C}$ & 0.9600 \\
$\mathrm{O} 3-\mathrm{C} 4$ & $1.436(4)$ & $\mathrm{C} 11-\mathrm{H} 11 \mathrm{~A}$ & 0.9600 \\
$\mathrm{O} 4-\mathrm{C} 7$ & $1.419(4)$ & $\mathrm{C} 11-\mathrm{H} 11 \mathrm{~B}$ & 0.9600 \\
$\mathrm{O} 4-\mathrm{C} 5$ & $1.430(4)$ & $\mathrm{C} 11-\mathrm{H} 11 \mathrm{C}$ & 0.9600 \\
$\mathrm{O} 5-\mathrm{C} 7$ & $1.418(4)$ & $\mathrm{C} 12-\mathrm{H} 12 \mathrm{~A}$ & 0.9700
\end{tabular}




\begin{tabular}{|c|c|c|c|}
\hline $\mathrm{O} 5-\mathrm{C} 6$ & $1.436(4)$ & $\mathrm{C} 12-\mathrm{H} 12 \mathrm{~B}$ & 0.9700 \\
\hline $\mathrm{O} 6-\mathrm{C} 12$ & $1.416(4)$ & $\mathrm{C} 13-\mathrm{C} 14$ & $1.509(4)$ \\
\hline $\mathrm{O} 6-\mathrm{C} 13$ & $1.418(4)$ & $\mathrm{C} 13-\mathrm{H} 13 \mathrm{~A}$ & 0.9700 \\
\hline $\mathrm{N} 1-\mathrm{C} 15$ & $1.339(4)$ & $\mathrm{C} 13-\mathrm{H} 13 \mathrm{~B}$ & 0.9700 \\
\hline $\mathrm{N} 1-\mathrm{N} 2$ & $1.343(4)$ & $\mathrm{C} 14-\mathrm{C} 17$ & $1.377(4)$ \\
\hline $\mathrm{N} 2-\mathrm{C} 16$ & $1.339(4)$ & $\mathrm{C} 14-\mathrm{C} 15$ & $1.411(4)$ \\
\hline $\mathrm{N} 3-\mathrm{C} 18$ & $1.330(5)$ & $\mathrm{C} 15-\mathrm{C} 23$ & $1.493(4)$ \\
\hline $\mathrm{N} 3-\mathrm{C} 22$ & $1.337(5)$ & $\mathrm{C} 16-\mathrm{C} 17$ & $1.397(4)$ \\
\hline $\mathrm{N} 4-\mathrm{C} 27$ & $1.339(5)$ & $\mathrm{C} 16-\mathrm{C} 18$ & $1.488(4)$ \\
\hline $\mathrm{N} 4-\mathrm{C} 23$ & $1.341(4)$ & C17-H17 & 0.9300 \\
\hline $\mathrm{C} 1-\mathrm{C} 12$ & $1.506(5)$ & $\mathrm{C} 18-\mathrm{C} 19$ & $1.394(5)$ \\
\hline $\mathrm{C} 1-\mathrm{C} 6$ & $1.510(5)$ & $\mathrm{C} 19-\mathrm{C} 20$ & $1.386(5)$ \\
\hline $\mathrm{C} 1-\mathrm{H} 1$ & 0.9800 & C19-H19 & 0.9300 \\
\hline $\mathrm{C} 2-\mathrm{C} 4$ & $1.519(5)$ & $\mathrm{C} 20-\mathrm{C} 21$ & $1.378(6)$ \\
\hline $\mathrm{C} 2-\mathrm{H} 2$ & 0.9800 & $\mathrm{C} 20-\mathrm{H} 20$ & 0.9300 \\
\hline $\mathrm{C} 3-\mathrm{C} 10$ & $1.508(5)$ & $\mathrm{C} 21-\mathrm{C} 22$ & $1.385(5)$ \\
\hline $\mathrm{C} 3-\mathrm{C} 11$ & $1.514(5)$ & $\mathrm{C} 21-\mathrm{H} 21$ & 0.9300 \\
\hline $\mathrm{C} 4-\mathrm{C} 5$ & $1.517(4)$ & $\mathrm{C} 22-\mathrm{H} 22$ & 0.9300 \\
\hline $\mathrm{C} 4-\mathrm{H} 4$ & 0.9800 & $\mathrm{C} 23-\mathrm{C} 24$ & $1.388(5)$ \\
\hline $\mathrm{C} 5-\mathrm{C} 6$ & $1.525(4)$ & $\mathrm{C} 24-\mathrm{C} 25$ & $1.382(5)$ \\
\hline $\mathrm{C} 5-\mathrm{H} 5$ & 0.9800 & $\mathrm{C} 24-\mathrm{H} 24$ & 0.9300 \\
\hline $\mathrm{C} 6-\mathrm{H} 6$ & 0.9800 & $\mathrm{C} 25-\mathrm{C} 26$ & $1.383(5)$ \\
\hline $\mathrm{C} 7-\mathrm{C} 8$ & $1.492(6)$ & $\mathrm{C} 25-\mathrm{H} 25$ & 0.9300 \\
\hline $\mathrm{C} 7-\mathrm{C} 9$ & $1.512(5)$ & $\mathrm{C} 26-\mathrm{C} 27$ & $1.375(6)$ \\
\hline $\mathrm{C} 8-\mathrm{H} 8 \mathrm{~A}$ & 0.9600 & $\mathrm{C} 26-\mathrm{H} 26$ & 0.9300 \\
\hline $\mathrm{C} 8-\mathrm{H} 8 \mathrm{~B}$ & 0.9600 & $\mathrm{C} 27-\mathrm{H} 27$ & 0.9300 \\
\hline $\mathrm{C} 8-\mathrm{H} 8 \mathrm{C}$ & 0.9600 & $\mathrm{O} 7-\mathrm{H} 7 \mathrm{~A}$ & $0.84(2)$ \\
\hline C9-H9A & 0.9600 & $\mathrm{O} 7-\mathrm{H} 7 \mathrm{~B}$ & $0.86(2)$ \\
\hline $\mathrm{O} 1 \cdots \mathrm{O} 3$ & $3.153(2)$ & $\mathrm{C} 2 \cdots \mathrm{C} 4^{\mathrm{ii}}$ & 3.538 \\
\hline $\mathrm{O} 1 \cdots \mathrm{O} 4$ & $3.115(3)$ & $\mathrm{C} 2 \cdots \mathrm{H} 4^{\mathrm{ii}}$ & 2.96 \\
\hline $\mathrm{O} 1 \cdots \mathrm{O} 5$ & $2.999(3)$ & $\mathrm{C} 3 \cdots \mathrm{H} 1$ & 2.88 \\
\hline $\mathrm{O} 1 \cdots \mathrm{O} 6$ & $2.920(3)$ & $\mathrm{C} 4 \cdots \mathrm{H} 11 \mathrm{~A}$ & 2.84 \\
\hline $\mathrm{O} 3 \cdots \mathrm{O} 1$ & $3.153(2)$ & $\mathrm{C} 4 \cdots \mathrm{H} 2^{\mathrm{iii}}$ & 2.83 \\
\hline $\mathrm{O} 3 \cdots \mathrm{C} 1$ & $3.002(3)$ & $\mathrm{C} 4 \cdots \mathrm{H} 1$ & 2.76 \\
\hline $\mathrm{O} 7 \cdots \mathrm{O} 1$ & $3.112(3)$ & $\mathrm{C} 5 \cdots \mathrm{H} 9 \mathrm{~A}$ & 2.85 \\
\hline $\mathrm{O} 7 \cdots \mathrm{O} 6$ & $3.176(3)$ & $\mathrm{C} 10 \cdots \mathrm{H} 1$ & 2.93 \\
\hline $\mathrm{O} 7 \cdots \mathrm{N} 2^{\mathrm{i}}$ & $3.020(3)$ & $\mathrm{H} 1 \cdots \mathrm{H} 10 \mathrm{C}$ & 2.24 \\
\hline $\mathrm{O} 2 \cdots \mathrm{H} 1$ & 2.70 & $\mathrm{H} 2 \cdots \mathrm{H} 4^{\mathrm{ii}}$ & 2.44 \\
\hline $\mathrm{O} 2 \cdots \mathrm{H} 4^{\mathrm{ii}}$ & 2.90 & $\mathrm{H} 4 \cdots \mathrm{H} 11 \mathrm{~A}$ & 2.47 \\
\hline $\mathrm{O} 3 \cdots \mathrm{H} 1$ & 2.54 & H5 $\cdots \mathrm{H} 9 \mathrm{~A}$ & 2.56 \\
\hline $\mathrm{O} 3 \cdots \mathrm{H} 2^{\mathrm{iii}}$ & 2.51 & $\mathrm{H} 7 \mathrm{~A} \cdots \mathrm{H} 19^{\mathrm{i}}$ & 2.20 \\
\hline $\mathrm{O} 5 \cdots \mathrm{H} 12 \mathrm{~B}$ & 2.70 & $\mathrm{H} 7 \mathrm{~A} \cdots \mathrm{N} 1^{\mathrm{i}}$ & $2.84(3)$ \\
\hline $\mathrm{O} 5 \cdots \mathrm{H} 12 \mathrm{~A}$ & 2.77 & $\mathrm{H} 7 \mathrm{~A} \cdots \mathrm{N} 2^{\mathrm{i}}$ & $2.19(4)$ \\
\hline O6 $\cdots \mathrm{H} 17$ & 2.23 & $\mathrm{H} 7 \mathrm{~B} \cdots \mathrm{O} 1$ & $2.30(2)$ \\
\hline $\mathrm{O} 7 \cdots \mathrm{H} 19^{\mathrm{i}}$ & 2.64 & H7B $\cdots \mathrm{O} 6$ & $2.56(4)$ \\
\hline $\mathrm{N} 4 \cdots \mathrm{C} 13$ & $2.776(3)$ & H8A $\cdots \mathrm{H} 9 \mathrm{C}$ & 2.55 \\
\hline $\mathrm{N} 1 \cdots \mathrm{H} 24$ & 2.44 & H8B $\cdots H 9 B$ & 2.50 \\
\hline
\end{tabular}


$\mathrm{N} 2 \cdots \mathrm{H} 19$

$\mathrm{N} 3 \cdots \mathrm{H} 17$

$\mathrm{N} 4 \cdot \cdots \mathrm{H} 13 \mathrm{~A}$

$\mathrm{N} 4 \cdots \mathrm{H} 13 \mathrm{~B}$

$\mathrm{C} 1 \cdots \mathrm{C} 3$

$\mathrm{C} 2-\mathrm{O} 1-\mathrm{C} 1$

$\mathrm{C} 2-\mathrm{O} 2-\mathrm{C} 3$

$\mathrm{C} 3-\mathrm{O} 3-\mathrm{C} 4$

$\mathrm{C} 7-\mathrm{O} 4-\mathrm{C} 5$

$\mathrm{C} 7-\mathrm{O} 5-\mathrm{C} 6$

$\mathrm{C} 12-\mathrm{O} 6-\mathrm{C} 13$

C15-N1-N2

C16-N2-N1

$\mathrm{C} 18-\mathrm{N} 3-\mathrm{C} 22$

$\mathrm{C} 27-\mathrm{N} 4-\mathrm{C} 23$

$\mathrm{O} 1-\mathrm{C} 1-\mathrm{C} 12$

$\mathrm{O} 1-\mathrm{C} 1-\mathrm{C} 6$

$\mathrm{C} 12-\mathrm{C} 1-\mathrm{C} 6$

$\mathrm{O} 1-\mathrm{C} 1-\mathrm{H} 1$

$\mathrm{C} 12-\mathrm{C} 1-\mathrm{H} 1$

C6- 1 1- 1

$\mathrm{O} 1-\mathrm{C} 2-\mathrm{O} 2$

$\mathrm{O} 1-\mathrm{C} 2-\mathrm{C} 4$

$\mathrm{O} 2-\mathrm{C} 2-\mathrm{C} 4$

$\mathrm{O} 1-\mathrm{C} 2-\mathrm{H} 2$

$\mathrm{O} 2-\mathrm{C} 2-\mathrm{H} 2$

$\mathrm{C} 4-\mathrm{C} 2-\mathrm{H} 2$

$\mathrm{O} 3-\mathrm{C} 3-\mathrm{O} 2$

$\mathrm{O} 3-\mathrm{C} 3-\mathrm{C} 10$

$\mathrm{O} 2-\mathrm{C} 3-\mathrm{C} 10$

$\mathrm{O} 3-\mathrm{C} 3-\mathrm{C} 11$

$\mathrm{O} 2-\mathrm{C} 3-\mathrm{C} 11$

$\mathrm{C} 10-\mathrm{C} 3-\mathrm{C} 11$

$\mathrm{O} 3-\mathrm{C} 4-\mathrm{C} 5$

$\mathrm{O} 3-\mathrm{C} 4-\mathrm{C} 2$

$\mathrm{C} 5-\mathrm{C} 4-\mathrm{C} 2$

$\mathrm{O} 3-\mathrm{C} 4-\mathrm{H} 4$

$\mathrm{C} 5-\mathrm{C} 4-\mathrm{H} 4$

$\mathrm{C} 2-\mathrm{C} 4-\mathrm{H} 4$

$\mathrm{O} 4-\mathrm{C} 5-\mathrm{C} 4$

O4-C5-C6

C4-C5-C6

$\mathrm{O} 4-\mathrm{C} 5-\mathrm{H} 5$

C4- C5-H5

$\mathrm{C} 6-\mathrm{C} 5-\mathrm{H} 5$

$\mathrm{O} 5-\mathrm{C} 6-\mathrm{C} 1$

$\mathrm{O} 5-\mathrm{C} 6-\mathrm{C} 5$
2.56

2.46

2.56

2.54

3.485 (3)

$113.4(2)$

110.4 (2)

106.7 (2)

$107.6(2)$

$109.6(2)$

112.9 (2)

$121.1(3)$

$119.2(3)$

117.7 (3)

$117.2(3)$

$107.5(3)$

110.3 (2)

113.4 (3)

108.5

108.5

108.5

$111.0(3)$

$114.3(3)$

103.7 (3)

109.2

109.2

109.2

105.4 (2)

108.3 (3)

109.9 (3)

110.8 (3)

109.4 (3)

112.8 (3)

$107.3(2)$

$103.9(2)$

$114.6(3)$

110.3

110.3

110.3

$107.2(2)$

$104.1(2)$

$113.2(3)$

110.7

110.7

110.7

$109.8(3)$

$104.5(2)$
$\mathrm{H} 8 \mathrm{C} \cdot \mathrm{H} 11 \mathrm{C}^{\mathrm{ii}}$

H10A $\cdots$ H11C

H10B $\cdots \mathrm{H} 11 \mathrm{~B}$

H12A $\cdots$ H13B

$\mathrm{H} 10 \mathrm{~A}-\mathrm{C} 10-\mathrm{H} 10 \mathrm{~B}$

C3- $\mathrm{C} 10-\mathrm{H} 10 \mathrm{C}$

$\mathrm{H} 10 \mathrm{~A}-\mathrm{C} 10-\mathrm{H} 10 \mathrm{C}$

$\mathrm{H} 10 \mathrm{~B}-\mathrm{C} 10-\mathrm{H} 10 \mathrm{C}$

C3-C11-H11A

C3-C11-H11B

H11A-C11-H11B

C3-C11- $111 \mathrm{C}$

$\mathrm{H} 11 \mathrm{~A}-\mathrm{C} 11-\mathrm{H} 11 \mathrm{C}$

H11B-C11-H11C

$\mathrm{O} 6-\mathrm{C} 12-\mathrm{C} 1$

$\mathrm{O} 6-\mathrm{C} 12-\mathrm{H} 12 \mathrm{~A}$

$\mathrm{C} 1-\mathrm{C} 12-\mathrm{H} 12 \mathrm{~A}$

$\mathrm{O} 6-\mathrm{C} 12-\mathrm{H} 12 \mathrm{~B}$

$\mathrm{C} 1-\mathrm{C} 12-\mathrm{H} 12 \mathrm{~B}$

$\mathrm{H} 12 \mathrm{~A}-\mathrm{C} 12-\mathrm{H} 12 \mathrm{~B}$

$\mathrm{O} 6-\mathrm{C} 13-\mathrm{C} 14$

$\mathrm{O} 6-\mathrm{C} 13-\mathrm{H} 13 \mathrm{~A}$

C14-C13-H13A

O6- $113-\mathrm{H} 13 \mathrm{~B}$

C14-C13-H13B

H13A-C13-H13B

$\mathrm{C} 17-\mathrm{C} 14-\mathrm{C} 15$

C17-C14-C13

C15-C14-C13

$\mathrm{N} 1-\mathrm{C} 15-\mathrm{C} 14$

$\mathrm{N} 1-\mathrm{C} 15-\mathrm{C} 23$

$\mathrm{C} 14-\mathrm{C} 15-\mathrm{C} 23$

$\mathrm{N} 2-\mathrm{C} 16-\mathrm{C} 17$

N2-C16-C18

$\mathrm{C} 17-\mathrm{C} 16-\mathrm{C} 18$

C14-C17-C16

C14-C17-H17

C16-C17-H17

N3-C18-C19

N3-C18-C16

C19-C18-C16

$\mathrm{C} 20-\mathrm{C} 19-\mathrm{C} 18$

$\mathrm{C} 20-\mathrm{C} 19-\mathrm{H} 19$

C18-C19-H19

$\mathrm{C} 21-\mathrm{C} 20-\mathrm{C} 19$

$\mathrm{C} 21-\mathrm{C} 20-\mathrm{H} 20$
2.48

2.53

2.57

2.26

109.5

109.5

109.5

109.5

109.5

109.5

109.5

109.5

109.5

109.5

107.7 (2)

110.2

110.2

110.2

110.2

108.5

107.7 (2)

110.2

110.2

110.2

110.2

108.5

116.4 (3)

118.5 (3)

125.1 (3)

121.9 (3)

113.5 (3)

124.6 (3)

$121.9(3)$

117.5 (3)

120.5 (3)

119.3 (3)

120.3

120.3

122.9 (3)

115.1 (3)

122.0 (3)

118.5 (3)

120.8

120.8

119.1 (3)

120.5 


\begin{tabular}{|c|c|c|c|}
\hline $\mathrm{C} 1-\mathrm{C} 6-\mathrm{C} 5$ & $113.0(3)$ & $\mathrm{C} 19-\mathrm{C} 20-\mathrm{H} 20$ & 120.5 \\
\hline $\mathrm{O} 5-\mathrm{C} 6-\mathrm{H} 6$ & 109.8 & $\mathrm{C} 20-\mathrm{C} 21-\mathrm{C} 22$ & $118.3(3)$ \\
\hline $\mathrm{C} 1-\mathrm{C} 6-\mathrm{H} 6$ & 109.8 & $\mathrm{C} 20-\mathrm{C} 21-\mathrm{H} 21$ & 120.8 \\
\hline $\mathrm{C} 5-\mathrm{C} 6-\mathrm{H} 6$ & 109.8 & $\mathrm{C} 22-\mathrm{C} 21-\mathrm{H} 21$ & 120.8 \\
\hline $\mathrm{O} 5-\mathrm{C} 7-\mathrm{O} 4$ & $106.1(2)$ & $\mathrm{N} 3-\mathrm{C} 22-\mathrm{C} 21$ & $123.5(3)$ \\
\hline $\mathrm{O} 5-\mathrm{C} 7-\mathrm{C} 8$ & $109.6(4)$ & $\mathrm{N} 3-\mathrm{C} 22-\mathrm{H} 22$ & 118.2 \\
\hline $\mathrm{O} 4-\mathrm{C} 7-\mathrm{C} 8$ & $108.4(3)$ & $\mathrm{C} 21-\mathrm{C} 22-\mathrm{H} 22$ & 118.2 \\
\hline $\mathrm{O} 5-\mathrm{C} 7-\mathrm{C} 9$ & $109.3(3)$ & $\mathrm{N} 4-\mathrm{C} 23-\mathrm{C} 24$ & $122.6(3)$ \\
\hline $\mathrm{O} 4-\mathrm{C} 7-\mathrm{C} 9$ & $110.9(3)$ & $\mathrm{N} 4-\mathrm{C} 23-\mathrm{C} 15$ & $116.6(3)$ \\
\hline $\mathrm{C} 8-\mathrm{C} 7-\mathrm{C} 9$ & $112.3(3)$ & $\mathrm{C} 24-\mathrm{C} 23-\mathrm{C} 15$ & $120.8(3)$ \\
\hline $\mathrm{C} 7-\mathrm{C} 8-\mathrm{H} 8 \mathrm{~A}$ & 109.5 & $\mathrm{C} 25-\mathrm{C} 24-\mathrm{C} 23$ & $118.7(3)$ \\
\hline $\mathrm{C} 7-\mathrm{C} 8-\mathrm{H} 8 \mathrm{~B}$ & 109.5 & $\mathrm{C} 25-\mathrm{C} 24-\mathrm{H} 24$ & 120.7 \\
\hline $\mathrm{H} 8 \mathrm{~A}-\mathrm{C} 8-\mathrm{H} 8 \mathrm{~B}$ & 109.5 & $\mathrm{C} 23-\mathrm{C} 24-\mathrm{H} 24$ & 120.7 \\
\hline $\mathrm{C} 7-\mathrm{C} 8-\mathrm{H} 8 \mathrm{C}$ & 109.5 & $\mathrm{C} 24-\mathrm{C} 25-\mathrm{C} 26$ & $119.5(3)$ \\
\hline $\mathrm{H} 8 \mathrm{~A}-\mathrm{C} 8-\mathrm{H} 8 \mathrm{C}$ & 109.5 & $\mathrm{C} 24-\mathrm{C} 25-\mathrm{H} 25$ & 120.3 \\
\hline $\mathrm{H} 8 \mathrm{~B}-\mathrm{C} 8-\mathrm{H} 8 \mathrm{C}$ & 109.5 & $\mathrm{C} 26-\mathrm{C} 25-\mathrm{H} 25$ & 120.3 \\
\hline $\mathrm{C} 7-\mathrm{C} 9-\mathrm{H} 9 \mathrm{~A}$ & 109.5 & $\mathrm{C} 27-\mathrm{C} 26-\mathrm{C} 25$ & $117.7(3)$ \\
\hline $\mathrm{C} 7-\mathrm{C} 9-\mathrm{H} 9 \mathrm{~B}$ & 109.5 & $\mathrm{C} 27-\mathrm{C} 26-\mathrm{H} 26$ & 121.2 \\
\hline $\mathrm{H} 9 \mathrm{~A}-\mathrm{C} 9-\mathrm{H} 9 \mathrm{~B}$ & 109.5 & $\mathrm{C} 25-\mathrm{C} 26-\mathrm{H} 26$ & 121.2 \\
\hline $\mathrm{C} 7-\mathrm{C} 9-\mathrm{H} 9 \mathrm{C}$ & 109.5 & $\mathrm{~N} 4-\mathrm{C} 27-\mathrm{C} 26$ & $124.4(3)$ \\
\hline $\mathrm{H} 9 \mathrm{~A}-\mathrm{C} 9-\mathrm{H} 9 \mathrm{C}$ & 109.5 & $\mathrm{~N} 4-\mathrm{C} 27-\mathrm{H} 27$ & 117.8 \\
\hline $\mathrm{H} 9 \mathrm{~B}-\mathrm{C} 9-\mathrm{H} 9 \mathrm{C}$ & 109.5 & $\mathrm{C} 26-\mathrm{C} 27-\mathrm{H} 27$ & 117.8 \\
\hline $\mathrm{C} 3-\mathrm{C} 10-\mathrm{H} 10 \mathrm{~A}$ & 109.5 & $\mathrm{H} 7 \mathrm{~A}-\mathrm{O} 7-\mathrm{H} 7 \mathrm{~B}$ & $104(6)$ \\
\hline $\mathrm{C} 3-\mathrm{C} 10-\mathrm{H} 10 \mathrm{~B}$ & 109.5 & & \\
\hline $\mathrm{C} 15-\mathrm{N} 1-\mathrm{N} 2-\mathrm{C} 16$ & $-1.1(5)$ & $\mathrm{O} 1-\mathrm{C} 1-\mathrm{C} 12-\mathrm{O} 6$ & $77.8(3)$ \\
\hline $\mathrm{C} 2-\mathrm{O} 1-\mathrm{C} 1-\mathrm{C} 12$ & $-167.7(2)$ & $\mathrm{C} 6-\mathrm{C} 1-\mathrm{C} 12-\mathrm{O} 6$ & $-160.1(3)$ \\
\hline $\mathrm{C} 2-\mathrm{O} 1-\mathrm{C} 1-\mathrm{C} 6$ & $68.2(3)$ & $\mathrm{C} 12-\mathrm{O} 6-\mathrm{C} 13-\mathrm{C} 14$ & $-161.7(3)$ \\
\hline $\mathrm{C} 1-\mathrm{O} 1-\mathrm{C} 2-\mathrm{O} 2$ & $81.1(3)$ & $\mathrm{O} 6-\mathrm{C} 13-\mathrm{C} 14-\mathrm{C} 17$ & $8.0(4)$ \\
\hline $\mathrm{C} 1-\mathrm{O} 1-\mathrm{C} 2-\mathrm{C} 4$ & $-35.8(3)$ & $\mathrm{O} 6-\mathrm{C} 13-\mathrm{C} 14-\mathrm{C} 15$ & $-172.8(3)$ \\
\hline $\mathrm{C} 3-\mathrm{O} 2-\mathrm{C} 2-\mathrm{O} 1$ & $-115.1(3)$ & $\mathrm{N} 2-\mathrm{N} 1-\mathrm{C} 15-\mathrm{C} 14$ & $3.9(5)$ \\
\hline $\mathrm{C} 3-\mathrm{O} 2-\mathrm{C} 2-\mathrm{C} 4$ & $8.1(3)$ & $\mathrm{N} 2-\mathrm{N} 1-\mathrm{C} 15-\mathrm{C} 23$ & $-175.6(3)$ \\
\hline $\mathrm{C} 4-\mathrm{O} 3-\mathrm{C} 3-\mathrm{O} 2$ & $-27.7(3)$ & $\mathrm{C} 17-\mathrm{C} 14-\mathrm{C} 15-\mathrm{N} 1$ & $-3.3(5)$ \\
\hline $\mathrm{C} 4-\mathrm{O} 3-\mathrm{C} 3-\mathrm{C} 10$ & $-145.2(3)$ & $\mathrm{C} 13-\mathrm{C} 14-\mathrm{C} 15-\mathrm{N} 1$ & $177.6(3)$ \\
\hline $\mathrm{C} 4-\mathrm{O} 3-\mathrm{C} 3-\mathrm{C} 11$ & $90.5(3)$ & $\mathrm{C} 17-\mathrm{C} 14-\mathrm{C} 15-\mathrm{C} 23$ & $176.1(3)$ \\
\hline $\mathrm{C} 2-\mathrm{O} 2-\mathrm{C} 3-\mathrm{O} 3$ & $11.5(4)$ & $\mathrm{C} 13-\mathrm{C} 14-\mathrm{C} 15-\mathrm{C} 23$ & $-3.0(5)$ \\
\hline $\mathrm{C} 2-\mathrm{O} 2-\mathrm{C} 3-\mathrm{C} 10$ & $128.0(3)$ & $\mathrm{N} 1-\mathrm{N} 2-\mathrm{C} 16-\mathrm{C} 17$ & $-2.2(5)$ \\
\hline $\mathrm{C} 2-\mathrm{O} 2-\mathrm{C} 3-\mathrm{C} 11$ & $-107.7(3)$ & $\mathrm{N} 1-\mathrm{N} 2-\mathrm{C} 16-\mathrm{C} 18$ & $175.7(3)$ \\
\hline $\mathrm{C} 3-\mathrm{O} 3-\mathrm{C} 4-\mathrm{C} 5$ & $154.1(3)$ & $\mathrm{C} 15-\mathrm{C} 14-\mathrm{C} 17-\mathrm{C} 16$ & $0.0(5)$ \\
\hline $\mathrm{C} 3-\mathrm{O} 3-\mathrm{C} 4-\mathrm{C} 2$ & $32.4(3)$ & $\mathrm{C} 13-\mathrm{C} 14-\mathrm{C} 17-\mathrm{C} 16$ & $179.2(3)$ \\
\hline $\mathrm{O} 1-\mathrm{C} 2-\mathrm{C} 4-\mathrm{O} 3$ & $96.5(3)$ & $\mathrm{N} 2-\mathrm{C} 16-\mathrm{C} 17-\mathrm{C} 14$ & $2.7(5)$ \\
\hline $\mathrm{O} 2-\mathrm{C} 2-\mathrm{C} 4-\mathrm{O} 3$ & $-24.4(3)$ & $\mathrm{C} 18-\mathrm{C} 16-\mathrm{C} 17-\mathrm{C} 14$ & $-175.2(3)$ \\
\hline $\mathrm{O} 1-\mathrm{C} 2-\mathrm{C} 4-\mathrm{C} 5$ & $-20.2(4)$ & $\mathrm{C} 22-\mathrm{N} 3-\mathrm{C} 18-\mathrm{C} 19$ & $-0.8(5)$ \\
\hline $\mathrm{O} 2-\mathrm{C} 2-\mathrm{C} 4-\mathrm{C} 5$ & $-141.2(3)$ & $\mathrm{C} 22-\mathrm{N} 3-\mathrm{C} 18-\mathrm{C} 16$ & $177.7(3)$ \\
\hline $\mathrm{C} 7-\mathrm{O} 4-\mathrm{C} 5-\mathrm{C} 4$ & $147.7(3)$ & $\mathrm{N} 2-\mathrm{C} 16-\mathrm{C} 18-\mathrm{N} 3$ & $-171.4(3)$ \\
\hline $\mathrm{C} 7-\mathrm{O} 4-\mathrm{C} 5-\mathrm{C} 6$ & $27.5(3)$ & $\mathrm{C} 17-\mathrm{C} 16-\mathrm{C} 18-\mathrm{N} 3$ & $6.5(4)$ \\
\hline $\mathrm{O} 3-\mathrm{C} 4-\mathrm{C} 5-\mathrm{O} 4$ & $175.2(2)$ & $\mathrm{N} 2-\mathrm{C} 16-\mathrm{C} 18-\mathrm{C} 19$ & $7.1(5)$ \\
\hline $\mathrm{C} 2-\mathrm{C} 4-\mathrm{C} 5-\mathrm{O} 4$ & $-70.0(3)$ & $\mathrm{C} 17-\mathrm{C} 16-\mathrm{C} 18-\mathrm{C} 19$ & $-174.9(3)$ \\
\hline
\end{tabular}




$\begin{array}{llll}\mathrm{O} 3-\mathrm{C} 4-\mathrm{C} 5-\mathrm{C} 6 & -70.5(3) & \mathrm{N} 3-\mathrm{C} 18-\mathrm{C} 19-\mathrm{C} 20 & 0.9(5) \\ \mathrm{C} 2-\mathrm{C} 4-\mathrm{C} 5-\mathrm{C} 6 & 44.2(4) & \mathrm{C} 16-\mathrm{C} 18-\mathrm{C} 19-\mathrm{C} 20 & -177.5(3) \\ \mathrm{C} 7-\mathrm{O} 5-\mathrm{C} 6-\mathrm{C} 1 & -121.7(3) & \mathrm{C} 18-\mathrm{C} 19-\mathrm{C} 20-\mathrm{C} 21 & -0.5(5) \\ \mathrm{C} 7-\mathrm{O} 5-\mathrm{C} 6-\mathrm{C} 5 & -0.3(4) & \mathrm{C} 19-\mathrm{C} 20-\mathrm{C} 21-\mathrm{C} 22 & 0.1(5) \\ \mathrm{O} 1-\mathrm{C} 1-\mathrm{C} 6-\mathrm{O} 5 & 76.1(3) & \mathrm{C} 18-\mathrm{N} 3-\mathrm{C} 22-\mathrm{C} 21 & 0.4(5) \\ \mathrm{C} 12-\mathrm{C} 1-\mathrm{C} 6-\mathrm{O} 5 & -44.5(4) & \mathrm{C} 20-\mathrm{C} 21-\mathrm{C} 22-\mathrm{N} 3 & -0.1(6) \\ \mathrm{O} 1-\mathrm{C} 1-\mathrm{C} 6-\mathrm{C} 5 & -40.1(3) & \mathrm{C} 27-\mathrm{N} 4-\mathrm{C} 23-\mathrm{C} 24 & -0.9(5) \\ \mathrm{C} 12-\mathrm{C} 1-\mathrm{C} 6-\mathrm{C} 5 & -160.7(3) & \mathrm{C} 27-\mathrm{N} 4-\mathrm{C} 23-\mathrm{C} 15 & -178.8(3) \\ \mathrm{O} 4-\mathrm{C} 5-\mathrm{C} 6-\mathrm{O} 5 & -16.4(3) & \mathrm{N} 1-\mathrm{C} 15-\mathrm{C} 23-\mathrm{N} 4 & 167.1(3) \\ \mathrm{C} 4-\mathrm{C} 5-\mathrm{C} 6-\mathrm{O} 5 & -132.5(3) & \mathrm{C} 14-\mathrm{C} 15-\mathrm{C} 23-\mathrm{N} 4 & -12.4(5) \\ \mathrm{O} 4-\mathrm{C} 5-\mathrm{C} 6-\mathrm{C} 1 & 102.9(3) & \mathrm{N} 1-\mathrm{C} 15-\mathrm{C} 23-\mathrm{C} 24 & -10.8(4) \\ \mathrm{C} 4-\mathrm{C} 5-\mathrm{C} 6-\mathrm{C} 1 & -13.2(4) & \mathrm{C} 14-\mathrm{C} 15-\mathrm{C} 23-\mathrm{C} 24 & 169.7(3) \\ \mathrm{C} 6-\mathrm{O} 5-\mathrm{C} 7-\mathrm{O} 4 & 17.2(4) & \mathrm{N} 4-\mathrm{C} 23-\mathrm{C} 24-\mathrm{C} 25 & 0.4(5) \\ \mathrm{C} 6-\mathrm{O} 5-\mathrm{C} 7-\mathrm{C} 8 & 134.1(3) & \mathrm{C} 15-\mathrm{C} 23-\mathrm{C} 24-\mathrm{C} 25 & 178.2(3) \\ \mathrm{C} 6-\mathrm{O} 5-\mathrm{C} 7-\mathrm{C} 9 & -102.4(3) & \mathrm{C} 23-\mathrm{C} 24-\mathrm{C} 25-\mathrm{C} 26 & 0.2(6) \\ \mathrm{C} 5-\mathrm{O} 4-\mathrm{C} 7-\mathrm{O} 5 & -28.3(4) & \mathrm{C} 24-\mathrm{C} 25-\mathrm{C} 26-\mathrm{C} 27 & -0.3(6) \\ \mathrm{C} 5-\mathrm{O} 4-\mathrm{C} 7-\mathrm{C} 8 & -146.0(3) & \mathrm{C} 23-\mathrm{N} 4-\mathrm{C} 27-\mathrm{C} 26 & 0.8(6) \\ \mathrm{C} 5-\mathrm{O} 4-\mathrm{C} 7-\mathrm{C} 9 & 90.3(3) & \mathrm{C} 25-\mathrm{C} 26-\mathrm{C} 27-\mathrm{N} 4 & -0.3(7) \\ \mathrm{C} 13-\mathrm{O} 6-\mathrm{C} 12-\mathrm{C} 1 & 174.4(3) & & \end{array}$

Symmetry codes: (i) $-x, y-1 / 2,-z+1 / 2$; (ii) $x-1 / 2,-y+1 / 2,-z+1$; (iii) $x+1 / 2,-y+1 / 2,-z+1$.

Hydrogen-bond geometry $\left(A,{ }^{\circ}\right)$

$\mathrm{Cg}$ is the centroid of the $\mathrm{N} 3 / \mathrm{C} 18-\mathrm{C} 22$ ring.

\begin{tabular}{lllll}
\hline$D-\mathrm{H} \cdots A$ & $D-\mathrm{H}$ & $\mathrm{H} \cdots A$ & $D \cdots A$ & $D-\mathrm{H} \cdots A$ \\
\hline $\mathrm{O} 7-\mathrm{H} 7 A \cdots \mathrm{N} 2^{\mathrm{i}}$ & $0.84(2)$ & $2.18(3)$ & $3.019(4)$ & $172(6)$ \\
$\mathrm{O} 7-\mathrm{H} 7 B \cdots \mathrm{O} 1$ & $0.86(2)$ & $2.30(3)$ & $3.112(4)$ & $157(6)$ \\
$\mathrm{O} 7-\mathrm{H} 7 B \cdots \mathrm{O} 6$ & $0.86(2)$ & $2.57(5)$ & $3.176(5)$ & $129(5)$ \\
$\mathrm{C} 2-\mathrm{H} 2 \cdots 3^{\mathrm{ii}}$ & 0.98 & 2.51 & $3.444(4)$ & 160 \\
$\mathrm{C} 12-\mathrm{H} 12 A \cdots C g^{\mathrm{iv}}$ & 0.97 & 3.07 & $3.761(3)$ & 130 \\
\hline
\end{tabular}

Symmetry codes: (i) $-x, y-1 / 2,-z+1 / 2$; (ii) $x-1 / 2,-y+1 / 2,-z+1$; (iv) $-x+1, y-1 / 2,-z+1 / 2$. 